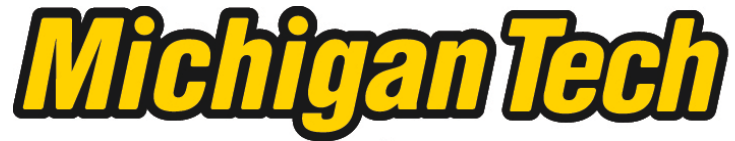 \\ Michigan Technological University Create the Future Digital Commons @ Michigan Tech
}

Dissertations, Master's Theses and Master's Reports - Open

Dissertations, Master's Theses and Master's

Reports

2011

\section{Nongovernmental organization staff views of global water privatization}

Ellis Adjei Adams

Michigan Technological University

Follow this and additional works at: https://digitalcommons.mtu.edu/etds

Part of the Environmental Policy Commons

Copyright 2011 Ellis Adjei Adams

\section{Recommended Citation}

Adams, Ellis Adjei, "Nongovernmental organization staff views of global water privatization", Master's Thesis, Michigan Technological University, 2011.

https://doi.org/10.37099/mtu.dc.etds/297

Follow this and additional works at: https://digitalcommons.mtu.edu/etds

Part of the Environmental Policy Commons 


\title{
NONGOVERNMENTAL ORGANIZATION STAFF VIEWS OF GLOBAL WATER PRIVATIZATION
}

\author{
By \\ Ellis Adjei Adams \\ A THESIS \\ Submitted in partial fulfillment of the requirements for the degree of \\ MASTER OF SCIENCE \\ (Environmental Policy)
}

MICHIGAN TECHNOLOGICAL UNIVERSITY

2011

Copyright $\mathbb{C}$ Ellis Adjei Adams 2011 
This thesis "Nongovernmental Organization Staff Views of Global Water Privatization," is hereby approved in partial fulfillment of the requirements of the Degree of MASTER OF SCIENCE IN ENVIRONMENTAL POLICY.

\section{Department of Social Sciences}

Signatures:

Thesis Advisor:

Professor Kathleen E. Halvorsen

Department Chair:

Professor Patrick Martin

Date: 


\section{Table of Contents}

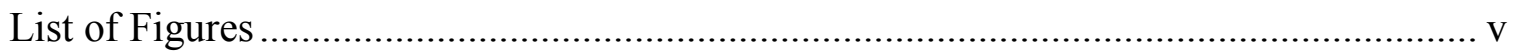

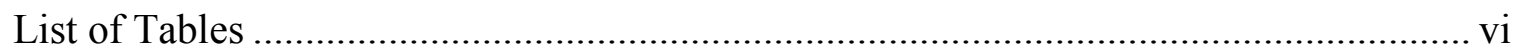

Acknowledgements .............................................................................................. vii

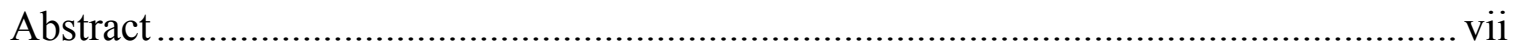

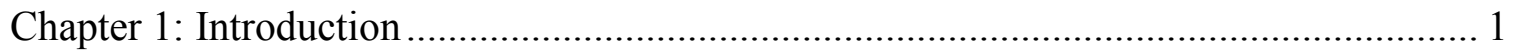

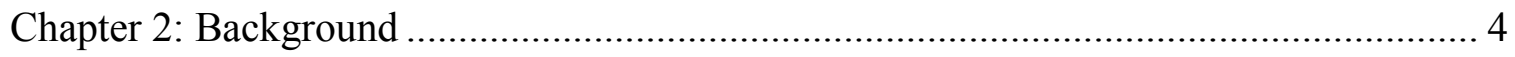

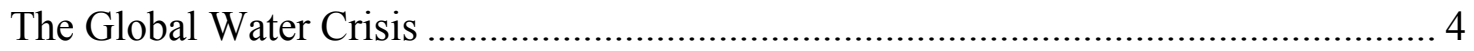

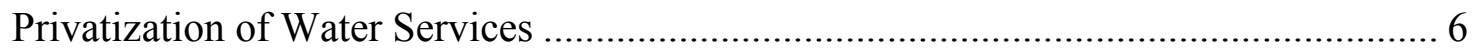

The Millennium Development Goals and Water Privatization....................................... 10

Media Portrayal of Water Privatization ..................................................................... 12

Chapter 3: Water Privatization Cases ……………………......................................... 15

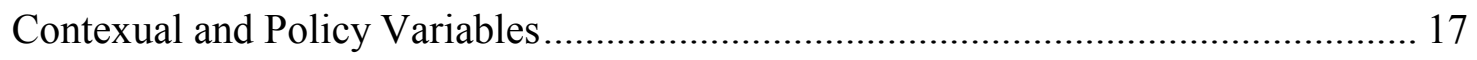

Case Study: Manilla, Philippines.......................................................................... 18

Case Study: Cochabamba, Bolivia................................................................................ 20

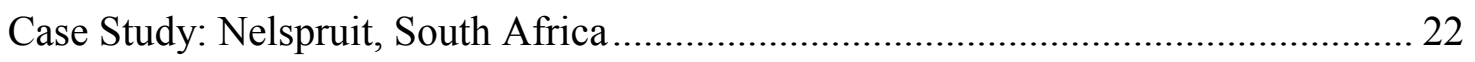

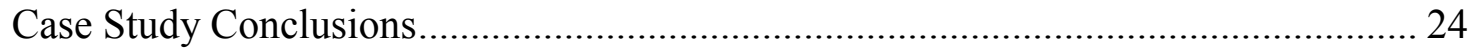

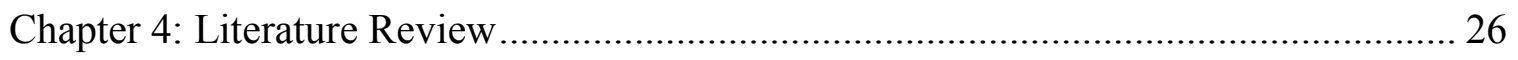

Water Privatization Research Populations................................................................. 27

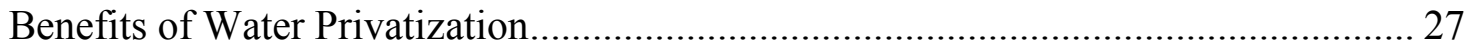

Water Privatization and Public Health.................................................................... 28

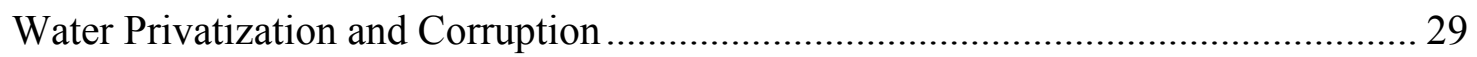

Public Resistance to Water Privatization........................................................................ 30

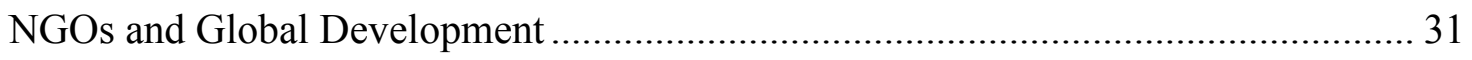

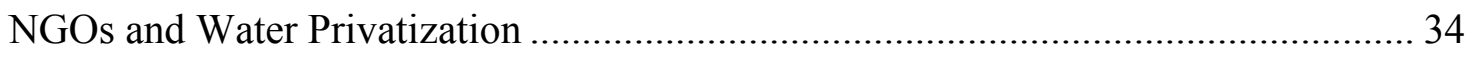

Chapter 5: Research Design..................................................................................... 36

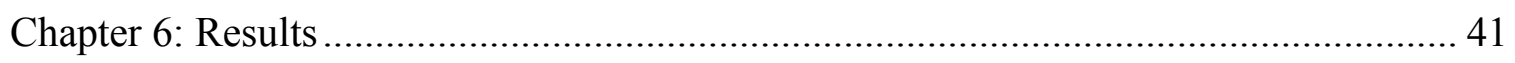

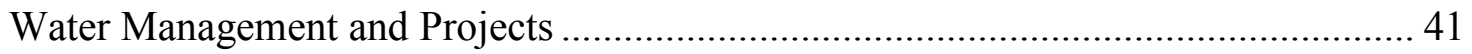


Water Project Evaluation and Assessment .......................................................... 42

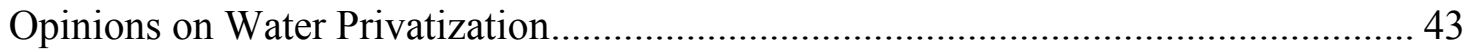

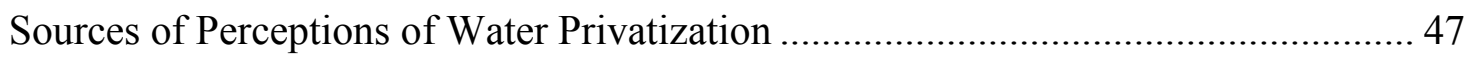

Water Privatization and NGO Decision Making ...................................................... 49

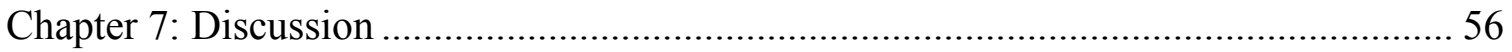

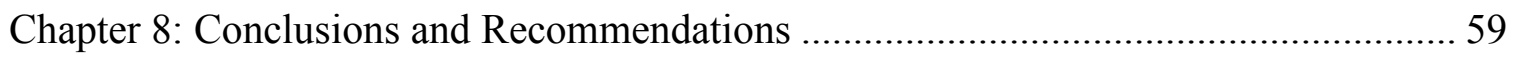

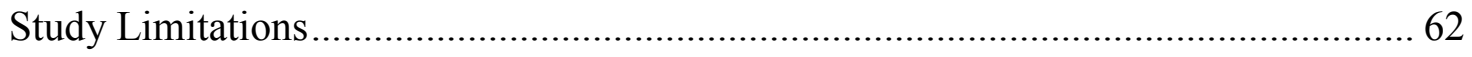

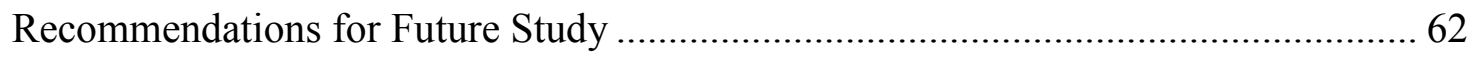

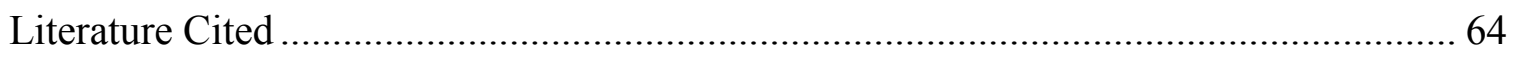

Appendix A: Interview Questions Protocol ........................................................... 78

Human Subjects Research Approval Number: M0691 ............................................. 78 


\section{List of Figures}

Fig 2.1: Regional distribution of people without improved drinking water .......................5

Fig 2.2: Regional distribution of people without improved sanitation ..............................5

Fig 3.1: Water Privatization by Region ................................................................. 15

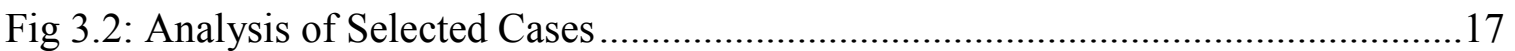




\section{List of Tables}

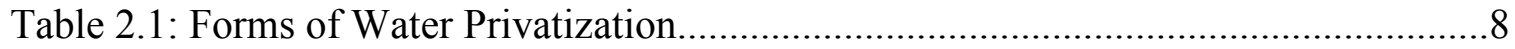

Table 2.2: Numbers Needed for United Nations Water MDG Achievement ...................11

Table 6.1: Criteria for WASH Project Assessment and Evaluation ................................43

Table 6.2: Interviewee Perceptions of Water Privatization .............................................46

Table 6.3: Sources of Beliefs about Water Privatization .............................................49

Table 6.4: Water Privatization and Interviewee Decision Making .................................52

Table 6.5: Water Privatization Perceptions between International and Local NGO Staff 54

Table 6.6: Perceptions of Water Privatization Failure ..................................................55 


\section{Acknowledgements}

To God be all the glory. Great things he has done, greater things he will do.

My utmost thanks go to Professor Kathleen Halvorsen. Kathy, I am forever indebted to you for your immeasurable support, guidance, and healthy criticisms throughout my academic journey at Michigan Technological University. I can never thank you enough. I also want to extend my appreciation to my committee members Professor Alex Mayer and Mark Reoleu for their useful comments and advice.

I would also like to thank all the NGO staff who participated in this study. Your responses were vital to the success of this study. I could not have made it this far without your input.

All friends and colleagues at Michigan Technological University deserve special mention. Special thanks to the African Students Organization and all the Ghanaian students whose warm friendships made this place seem like home.

Last but not the least I will like to thank all my family members and siblings who contributed in diverse ways towards my academic success. Thank you mom for the legacy of love and thank you Dad for the legacy of hard work and discipline. 


\begin{abstract}
More than 1 billion people lack access to clean water and proper sanitation. As part of efforts to solve this problem, there is a growing shift from public to private water management led by The World Bank and the International Monetary Fund (IMF). This shift has inspired much related research. Researchers have assessed water privatization related perceptions of consumers, government officials, and multinational company agents.
\end{abstract}

This thesis presents results of a study of nongovernmental (NGO) staff perceptions of water privatization. Although NGOs are important actors in sustainable water related development through water provision, we have little understanding of their perceptions of water privatization and how it impacts their activities. My goal was to fill this gap. I sampled international and national development NGOs with water, sanitation, and hygiene (WASH) foci. I conducted 28 interviews between January and June of 2011 with staff in key positions including water policy analysts, program officers, and project coordinators. Their perceptions of water privatization were mixed. I also found that local water privatization in most cases does not influence NGO decisions to conduct projects in a region. I found that development NGO staff base their beliefs about water privatization on a mix of personal experience and media coverage. My findings have important implications for the WASH sector as we work to solve the worsening global water access crisis. 


\section{Chapter 1: Introduction}

Safe and affordable clean water is essential to human survival and societal development. Unfortunately, it is a luxury to many across the globe. The World Health Organization (WHO) reported that over 1.1 billion people lack access to sufficient supplies of clean water while 2 billion also lack adequate sanitation (WHO 2011). This situation has led to waterborne disease crisis.

Scientists and policy makers have suggested various solutions. These include rainwater harvesting and water reuse and recycling (Pereira et al. 2002), increasing irrigation efficiency (Postel 1998), public private water management partnerships (Lobina and Hall 2007) and the privatization of the water and sanitation (WASH) sector (Fuest and Haffner 2007).

The promotion of private sector involvement in water services in developing countries dates back to the late twentieth century. Following the 1989 Washington Consensus, neoliberal economic increased in development circles. The early decades of the twenty-first century witnessed tremendous growth in the production, distribution, and management of water services and other utilities by multinational companies (Palaniappan et al. 2004).

Water privatization proponents cite rationales ranging from the need for increased water sector capital investment to inefficiencies in many public water systems to support their arguments. Water privatization critics counter with arguments that privatization results in unaffordable water rate increases, closed contractual processes, decreased 
public sector employment, and detrimental shifts to solely profit-focused water service provision.

Problems associated with water privatization have been largely blamed on the multinational companies who often administer the contracts. However, the reluctance of many countries to invest in public water systems is another reason for inadequate water access levels. The World Bank and the International Monetary Fund (IMF) have led the privatization trend arguing that public utilities are often poorly administered. These organizations often require that developing countries privatize their WASH sectors to qualify for IMF and World Bank loans and grants (Barlow and Clark 2002).

Global water privatization growth has inspired many scientific studies. These studies have revealed both successes and failures. The central questions of the water privatization debate focuses on whether it is more effective than public WASH sectors at increasing water access (Mustafa and Reeder 2009; Wu and Malaluan 2008; Zaki and Amin 2009). Empirically based water privatization research has largely focused on surveying or interviewing consumers, government officials, or private company workers. The research findings have been mixed.

International and national development NGO staff play important roles in the provision of development country water and sanitation and development policy formation yet they have not been included in these studies. In an attempt to fill this gap, my objectives for this study are twofold; to understand the development NGO staff perceptions of water privatization and to understand how the presence of regional water privatization affects their choices of whether to site projects there. 
My study will increase our understanding of the water privatization debate from the standpoint of people directly engaged in on the ground water provision. Understanding this will provide better information to developing country governments and policy makers as to the important factors to consider when reforming the water sector.

My objective is neither to critique water privatization nor to support it as a panacea to the global water crisis. However, taking a position that is neither pro or anti privatization, my aim is to contribute to the larger context of the water privatization debate through the analysis and interpretation of views held by officials in development international and national/local NGOs. 


\section{Chapter 2: Background}

Globally, accessible and readily available water comes in the form of freshwater, and makes up less than $1 \%$ of the total available fresh water resources (Pimentel et al. 1997). Nonetheless, this limited amount has been subjected to various anthropogenic threats resulting in water quality and quantity deteriorations. This has caused extreme water shortages in many parts of the globe. Climate change has also led to dwindling freshwater resources (Postel 1998). In the future, water scarcity is predicted to be a major constraint on agricultural production and food security globally, with most severe shortages in the arid regions in Africa and Asia (Postel 1998).

\section{The Global Water Crisis}

One of the most pressing problems of the $21^{\text {st }}$ century is the lack of access to clean affordable water. With over 1 billion people unable to access clean water and more than 2 billion lacking improved sanitation, there are severe implications for human health and strong impacts on economic growth and development (WHO 2011). Furthermore, the water crisis picture looks even gloomier in rural areas. According to the WHO (2008), $84 \%$ of the global rural populations are without access to safe drinking. Fig 2.1 and 2.2 depicts the regional distribution of people without access to clean water and improved sanitation facilities. 


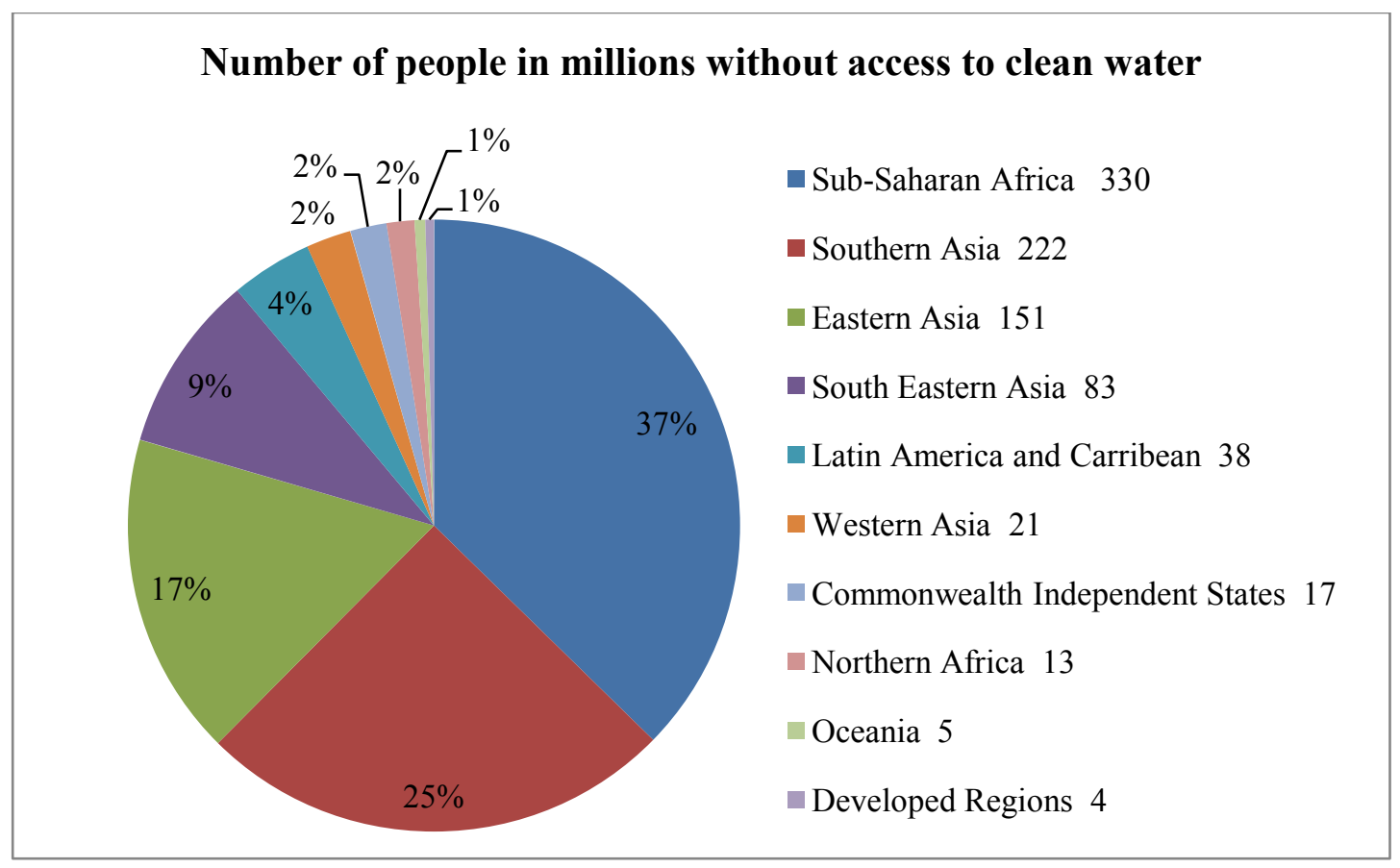

Fig 2.1 Regional distribution of people without clean water access (WHO 2010).

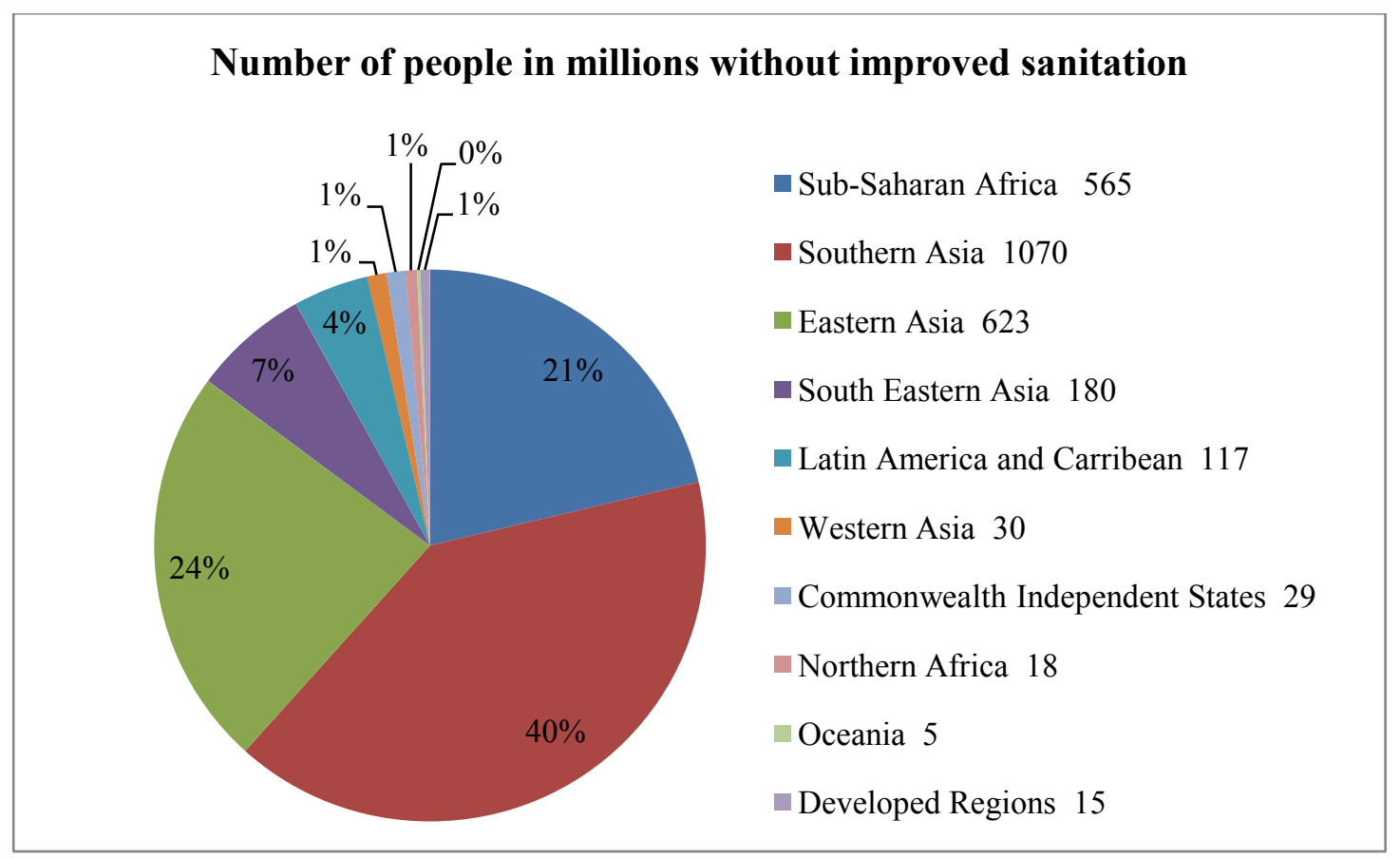

Fig 2.2 Regional distribution of people without improved sanitation (WHO 2010). 
From the figures 2.1 and 2.2, the regional situation of the water and sanitation crisis is worse in Sub Saharan Africa and Asia. Coupled with this, many areas around the world especially in the Middle East and Northern Africa are also predicted to experience chronic water shortages by 2025 (USAID 2007). The lack of adequate clean water remains the single most important cause of illness among children in developing countries (UNICEF 2010). For developing countries, ineffective drinking water treatment coupled with inadequate health care provision increases waterborne disease mortality rates. With increasing water consumption from population growth and urbanization, coupled with climate change, the global water crisis is expected to worsen if policies are not implemented (Ashton 2002). These trends have facilitated arguments for new water governance paradigms. The privatization of water services is one of the most popular.

\section{Privatization of Water Services}

The concept of water services provision has different dimensions. Before freshwater is pumped and supplied for domestic use, it undergoes purification treatment for safe consumption. Prior to its supply for municipal use, it sometimes has to be stored in tanks. The treatment, storage, and supply require infrastructure and capital. Thus, water service is a very broad term which encapsulates various stages from the freshwater resource to supply for either industrial, agricultural, or domestic purposes.

The term water privatization has been subject to much debate. It can be used to indicate all forms of private sector participation in the water sector whether the private 
agency emerges from within a country or from outside. Water privatization can also include the services of small scale water vendors operating especially in slums and periurban areas of developing countries (Solo 1999). For the purposes of this study, I focus on large scale forms of water privatization presented in Table 2.1. It involves the activities of large multinational companies whose activities of water supply are limited mainly to urban areas. For this study, I define water privatization the transfer of either part, or all of the production, distribution, or management of water services from public to private multinational companies (Gleick et al. 2002).

During the early twentieth century, economic neoliberal reforms that recognized water as an economic good were strongly promoted in developed countries such as England, Wales, and France (Castro 2008). Over time, these ideas took hold in parts of Africa, Asia, and Latin America. Although private control of water services constitutes only $5 \%$ of the global water provision, there are estimates that by the year 2015 , private firms will be supplying water to about 1.2 billion people across the globe (Budds and McGranahan 2003; Goldman 2007). Water privatization is expected to become more common in developing regions like Sub Saharan Africa, Asia, and Latin America (Budds and McGranahan 2003). In Table 2.1, I present the different models of water privatization based on asset ownership, duration of contract, management, and capital investment. 
Table 2.1

Forms of water privatization.

\begin{tabular}{|c|c|c|c|c|}
\hline Type & Ownership & Management & Investment & $\begin{array}{c}\text { Typical } \\
\text { Duration }\end{array}$ \\
\hline $\begin{array}{c}\text { Management } \\
\text { contract }\end{array}$ & Public & Private & Public & $2-5$ years \\
\hline $\begin{array}{c}\text { Lease/ } \\
\text { Affermage }\end{array}$ & Public & Private & Public & $8-20$ years \\
\hline Concession & Public & Private & Private & $20-30$ years \\
\hline Divestiture & Private & Private & Private & $\begin{array}{c}\text { Fixed } / \text { open } \\
\text { term }\end{array}$ \\
\hline
\end{tabular}

Adapted from (Palaniappan et al 2004).

As Table 2.1 shows, management contracts are models in which asset ownership and capital investment rests with the government or public agency involved with the private company only responsible for the management of the system (Gleick et al. 2002). Leases are similar to management contracts with the only differences being that, contracts are for an extended period of time usually 8 to 20 years. In lease contracts, capital investment rests with the private company with asset ownership being the responsibility of the public. The divestiture and concession contract types are usually over 20 years (Palaniappan et al. 2004).

Implementing water privatization as part of the solution identification process to the global water crisis has involved many organizations and political actors. These include governments, international financial institutions such as the World Bank and the IMF, and international multinational companies such as Suez and Vivendi. As conditions for loans, the World Bank and the IMF have influenced several developing countries to 
privatize water (Barlow and Clark 2002). Proponents of water privatization strongly argue that public water services are plagued with inefficiencies that can only be addressed by the private sector. Other reasons behind the growth of water privatization include the inability of the public sector to effectively manage water services, their reluctance to invest in these systems, high public water sector corruption levels, and pressure on governments to achieve UN Millennium Development Goals (MDG's). Also, water privatization usually occur as a monopoly, thus, private firms seldom face competition from other private water operators. Although the bidding process of water privatization is open to different multinational companies, contracts are often awarded to a single company which is given the mandate to manage water services within different municipalities or urban areas.

The question of whether of water privatization is a viable option to improve water access remains subject to much debate. It has been hailed as a water scarcity panacea by many. Some argue it can help meet the MDG's. Other evidence from some scientists indicate however that, with adequate support from governments, the public sector can effectively and efficiently manage water supply schemes (Lobina and Hall 2007).

With the growing gap between water demand and supply, economic reforms to privatize water utilities especially in developing countries is expected to grow. The advantages and disadvantages of both public and private water control is open to debate considering that several factors cause both systems to either fail or succeed. 


\section{The Millennium Development Goals and Water Privatization}

At the beginning of the $21^{\text {st }}$ Century, the United Nations set very ambitious MDGs to achieve by 2015. These goals aim to improve human conditions across the globe through development and poverty reduction. Governments are under enormous pressure to achieve the goals. However, many developing countries have inadequate financial resources for the levels of public utility investment required to meet the MDGs. The seventh of the eight goals aims at environmental sustainability and specifically aims to halve, by 2015, the proportion of the global population without access to safe drinking water and improved sanitation. Unfortunately, the proportion of people without access to safe water and sanitation seem to be increasing with growing population in second and third world countries (Hall and Lobina 2006). As a result, the per capita water available is reducing given that competition between domestic, industrial, and agricultural use over time is becoming more intensive. This has further aggravated the water crisis.

To achieve the seventh goal of the MDGs by 2015, water supply needs to be extended to an extra 1.6 billion people around the globe, with a quarter of this number located in Sub-Saharan Africa (Hall and Lobina 2006). This has increased the pressure on governments to involve the private sector in water and sanitation utilities provision as a means to drive faster towards the achievement of the MDGs (Barlow and Clarke 2002). The number of people needed to gain new water access in order to achieve the MDGs by 2015 is presented in Table 2.2. 
Table 2.2

Numbers needed for United Nations water MDG achievement

\begin{tabular}{|c|c|c|c|}
\hline Region & Urban (Millions) & Rural (Millions) & Total (Millions) \\
\hline $\begin{array}{c}\text { Sub-Saharan } \\
\text { Africa }\end{array}$ & 175 & 184 & 359 \\
\hline $\begin{array}{c}\text { Middle East and } \\
\text { North Africa }\end{array}$ & 104 & 30 & 134 \\
\hline South Asia & 243 & 201 & 444 \\
\hline East Asia & 290 & 174 & 465 \\
\hline Latin America & 121 & 20 & 141 \\
\hline Europe & 27 & 0 & 27 \\
\hline
\end{tabular}

Adapted from (Hall and Lobina, 2006)

As Table 2.2 shows, the largest proportion of people to which water should be made accessible globally is within Asia and Sub Saharan African region. This explains in part why water privatization is more common is those regions. With dwindling water resources, there is the need for efficient management to supply growing populations. To achieve the MDGs, water must be extended to as many as 1.57 billion people globally by 2015. This wide gap between supply and demand of water has been used as an argument in support of the claim that water privatization will be an efficient way of improving access to water and move faster towards achieving the MDGs. 


\section{Media Portrayal of Water Privatization}

Webpages, documentaries, magazines, and newspapers are some of the media sources of water privatization information. Large television and radio news media agencies such as Cable News Network (CNN) and British Broadcasting Corporation (BBC) publish global water privatization issues. On January 8, 2010, CNN hosted the president of Water Keeper Alliance, Robert Kennedy Jr, to share his thoughts on water privatization (Evans 2010). He was strongly opposed to water privatization on grounds that water should be a fundamental human right to both poor and rich people. He argued that the ultimate responsibility to supply water lie with governments and not private companies who are driven by profits.

The BBC has occasionally informed the public about the influential role the World Bank plays in developing country water privatization. On December 3, 2008, BBC reported news about the failure of water privatization to improve the water problems in the urban areas of Ghana (Hooker 2008). On April 30, 2008, BBC published an editorial on a rule by the South African government to outlaw forced prepaid meter installation by private water operators (BBC News 2008). When Northern Ireland ruled out the future prospects of water privatization, BBC published it as an editorial (BBC News 2007). The $\mathrm{BBC}$ has also reported issues of failed water privatization contracts. For example, in 2005, the termination of water privatization contracts in Tanzania and Brazil owing to poor private company performance was reported by the BBC (Cronin 2005).

Contrary to BBC's earlier negative portrayals of water privatization, it also published on August 13, 2007 that the solution to growing water scarcity lies in 
appropriate water charges that will motivate water conservation and also ensures adequate water sector investment (Brown 2007). Additionally, it also published an editorial about the growing public support for water privatization in Scotland (BBC News 2004).

Print media like newspapers and magazines are another source of water privatization information for the public. Some of the articles in the print media focus on the privatization of freshwater by large companies like Coca Cola and Nestle as well as municipal and urban water privatization. On December 12, 2005, the Time Magazine published an editorial on the environmental implications of growing privatization of freshwater supplies by Coca Cola and Nestle in parts of the United States (Times 2005). The Time Magazine also published an article on March 16, 2007 describing how large multinational companies like Vivendi and Suez basically make money from public water supplies (Graff 2007). The fight against water privatization in Ghana led by an activist Rudolf Amenga-Etego was also published by Times Magazine in 2004 (Robinson 2004).

The New York Times has published a number of articles on water privatization. One article described the cancellation of Atlanta's private water contract and the subsequent transfer to a public agency (Jehl 2003). On August 22, 2002, an article "As Multinationals Run the Taps, Anger Rises over Water for Profit” by Tagliabue (2002) was published in the New York Times. It discussed rising water charges from water privatization in Argentina and how activist groups and citizens called on the Argentine government to terminate the contract with Vivendi. 
The National Post newspaper published an article by Brubaker (2000) that supported the privatization of the sewage treatment facility in Halifax, Canada. The Hindu, a national newspaper in India published an editorial about New Delhi's campaign against water privatization by various activists and organizations citing that multinational companies are only concerned about their profits (The Hindu 2005). In response to water privatization in Indonesia, The Jakarta Post published 'Water privatization a controversial step around the world' in 2003 (Kurniawan 2003). The Japan Times and The New Straight Times in Malaysia both published the outcome of the third water forum with a caption 'Water forum closes amid clash over water privatization'. The authors argued that failed water privatization cases in Argentina, Bolivia, South Africa, and The Philippines inspired clashes at the forum (Ismail 2003; Johnston and Murakami 2003).

Flow, Thirst, and Tapped are documentaries based on water privatization experiences. Flow is about how multinational companies are making money from public water resources (Flow 2008). The basic theme of Flow that water is a human right and must remain in public control. Thirst centers on the opposition to water privatization by various communities from different regions (Thirst 2004). Tapped examined the environmental consequences of the bottled water industry (Tapped 2009). Most of the media information on water privatization focuses on the negative aspects of it. 


\section{Chapter 3: Water Privatization Cases}

Different areas and regions have had different experiences with water privatization. In the next section, I discuss through a comparative case analsysis, how water privatization played out in each case. These cases will help the reader to understand the dynamics of water privatization in different regions and help provide more background to my study. Figure 3.1 shows the trend of water privatization by region over the last two decades.

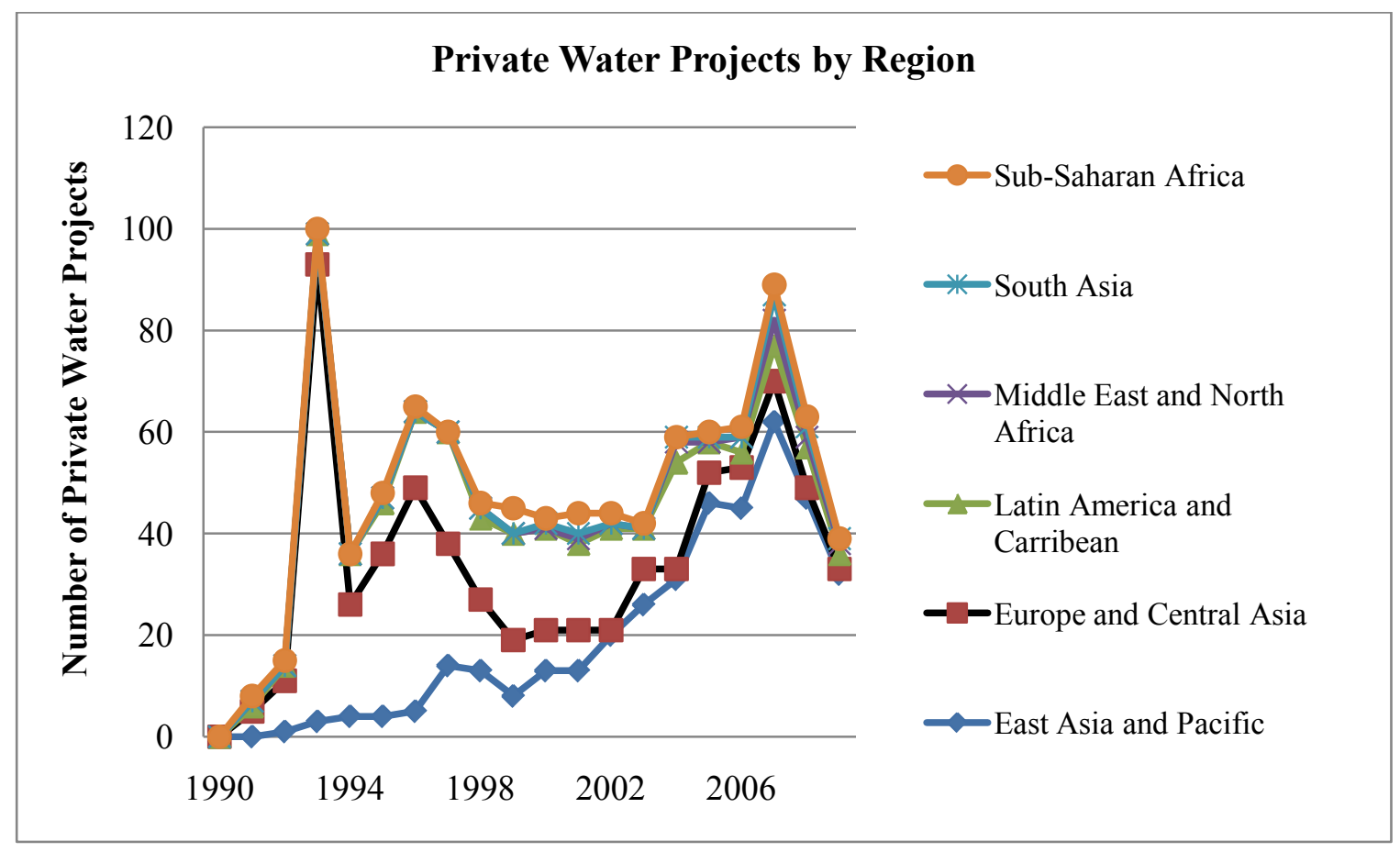

Fig 3.1 Water Privatization by Region. (Data obtained from The World Bank's PPI database). 
Sub-Saharan Africa, South Asia, and Latin America lead the number of private water projects across the globe. I describe one selected case of water privatization from each region. I selected the cases of Manila (Philippines), Cochabamba (Bolivia), and Nelspruit (South Africa). Although these countries differ in terms of the privatization contract type, country demographics, multinational company in charge of the water sector, and the dynamics of privatization process, they also share important similar characteristics that provoke interesting questions. For example, all three cases witnessed intense involvement of international financial institutions, in this case, the World Bank and the International Monetary Fund (IMF) prior to the privatization contract.

The individual cases possess characteristics that can illuminate our understanding of water privatization. The Manila water concession in the Philippines remain the biggest private water contract in a developing country (Marin 2009). The concession contract is ongoing and presents a peculiar case of long term private water contracts. South Africa has witnessed increased municipal water privatization amid intense public opposition (McDonald and Ruiters 2005). Furthermore, privatization of major sectors including water were instituted following the breakdown of racial apartheid rule in the country. The case of Nelspruit was chosen specificically for this analysis because it is the biggest water privatization contract awarded in South Africa where a private operator serves over 350, 000 people (McDonald and Ruiters 2005).

The case of Cochambamba was chosen for Latin America because it is noted for a water privatization war and presents an interesting picture of opposition to privatization. It is often cited as an example of water privatization failure (Barlow and Clark 2002). Out 
of the three cases, Cochabamba allows the analysis of a post withdrawal privatization experience since the privatization contract was terminated due to intense public opposition.

\section{Contexual and Policy Variables}

For each of the selected cases, I have identified key policy variables with which I compare and contrast the water privatization process. Key variables and sub-variables for the comparative analysis are summraized in Fig 3.2.

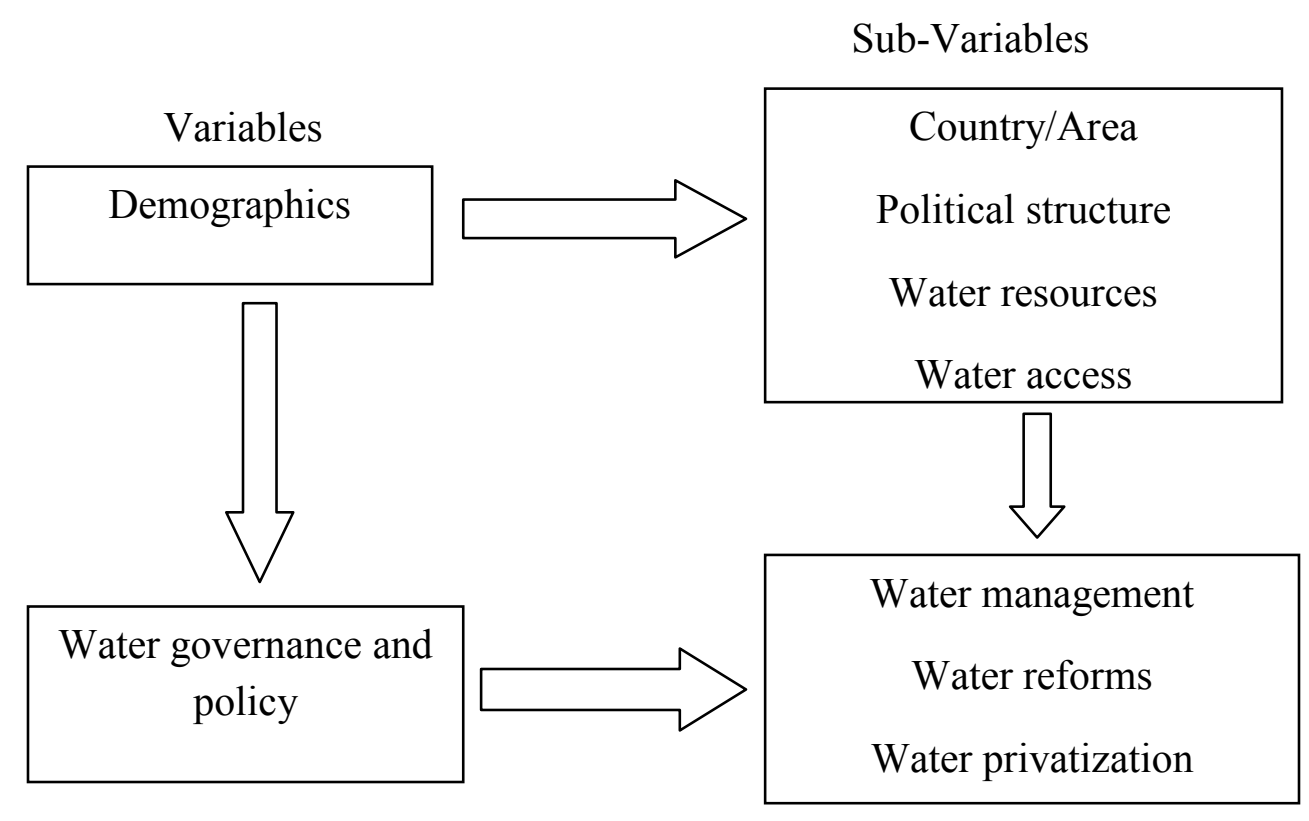

Fig 3.2 Analysis of selected cases 
Under demographics, I will discuss for each case study area, country characteristics and how it relates and differ from other case study countries. I also look at public sector reforms in relation to political changes within the last two decades. Based on this, I am able to deduce whether or not water sector reforms were carried out in isolation, or as part of massive public utilities reforms for each case study country. More importantly, the last variable for comparative analysis is the water privatization process and how the experiences in each of the cases compare and contrast with the other. I look holistically at the privatization process by focusing on the role different actors played. I will also discuss the aftermath of the privatization contract for each of the cases.

\section{Case Study: Manilla, Philippines}

Manila is the capital and industrial heart of Philippines and hosts about 20 million of the total Philipino population. It is the area where the concession water contract was handed over to a private company. Threats to freshwater resources include deforestation in watershed areas, pollution from agricultural run off, and discharges from municipal and industrial waste water (Conhead 2002). The 1990's witnessed massive transfer of 122 public water utilities to private companies in Phillipines (Foshee et al. 2008).

The Metropolitan Waterworks and Sewerage System (MWSS) struggled to keep up with growing water demands coupled with non-revenue water problems (Dumol 2000; Fisher 2009). As a result, the 1994's marked the beginning of the debate to privatize water on grounds that MWSS failed to meet the demands of the growing population 
within the Manila metropolis. Other reasons in support of privatization were allegations of corruption within the MWSS (Dumol 2000).

The Water Crisis Act of 1995 was passed allowing the president of Philippines power to negotiate water contracts including privatization of MWSS. Subsequent to this, Manila's Metropolitan Waterworks and Sewerage System (MWSS) was handed over to two private companies in 1997 under a 25 year concession. This was the biggest water concession contract globally. It was largely influenced by the International Finance Corporation (IFC) and The World Bank (Public Citizen 2003). The contracts were awarded jointly to Maynilad Water Services and the French firm Suez. The concession's objective was to improve water services coverage in the Manila Metropolis, expand infrastructure, and charge the private company to assume full responsibility of MWSS's debts (Public Citizen 2003).

The water privatization contract is ongoing. The outcome of the contract has not been very positive. Coverage of the poorer areas of Manila has been very slow (Wu and Malaluan 2008). The private water company became bankrupt due to soaring operating expenses beyond what they originally projected (Public Citizen 2003). Two years following the contract, more than 2 million people were connected to piped sources of water.This has largely been cited as an achievement of the privatization contract both in Philippines and globally (Dumol 2000).

The concession contract has not been immune from challenges. Within a year following the privatization, water charges increased. An estimated 2000 public workers were forced retire, and additional 750 workers later laid off due to bankrupcy (Public 
Citizen 2003). The private companies could not keep up with the contractual obligations and began call for renegotiation (Foshee et al. 2008).While the Manila company's operations continue to grow, Maynilad Water and Suez have pulled out of the concession contract on grounds that the City of Manila has not been supportive. Currently, a coaltion of activists and NGOs called Bantay Tubig are strongly calling for the termination of the privatization contract due to non-performance (Bantay Tubig 2010). This case illustrates how NGOs organize communities to oppose water privatization when private water companies fail to deliver on their contractual promises. Furthermore, it is a case in support of how private companies underperform withou cooperation from the communities they serve. Transparency and local community involvement in the contract process of water privatizaton is key to its success.

\section{Case Study: Cochabamba, Bolivia}

Bolivia remains one of the poorest countries in Latin America. Nearly three quarters of the Bolivian population live below the poverty line (Foshee et al. 2008). Major impacts on water resources within the country include the discharge of effluents and organic materials from agriculture and mining (US Army Corps 2004). Agriculture is the most water intensive industry and consumes 81 percent of the country's annual water use while 7 and 13 percent are respectively consumed through industry and domestic use (US Army Corps 2004). Countrywide coverage of water and sanitation services remain one of the poorest in Latin America with more than $40 \%$ of the population having no access to clean water (Public Citizen 2003). 
In the late twentieth century, Bolivia embarked on a massive decentralization and opened its public utilities to private markets. These economic policies were enforced on grounds of fewer jobs, unemployment, and deteriorating public working conditions (Olivera 2004). In 1999, the World Bank and the International Development Bank enticed the Bolivian government with a loan on condition that water and sanitation services be privatized. Subsequent to this, the Bolivian government passed a federal drinking water and sanitation act. This legalized privatization of water and sanitation services. In the mid 1990's, The World Bank gave 4.5 million dollars to the Bolivian Government to improve water infrastructure while seeking privatization as a condition (Spronk and Webber 2007). Prior to 1999, water provision in Cochabamba was the responsibility of the municipal public agency Servicio Autonomo Municipal de Agua Potable Alcantarilado (SAMAPA). The World Bank asserted that Bolivia did not have funds to ensure adequate investment in the water sector. As a result, the government was left with no option but to privatize (Fuente 2003).

The Bolivian government finally granted a 40 -year concession contract to the private company Aguas del Tunari in 1999. Immediately after the contract, water rates more than doubled to levels that the poor and local farmers were unable to afford (Barlow and Clark 2002; Perreault 2008; Public Citizen 2003).

In response to increased water charges, there was massive mobilization of civil society groups, NGOs, farmers, and other low class citizens demanding the termination of the privatization contract. The citizens activist group called La Coordinadora emerged consisting of local NGOs, human right advocates, and different classes of people to fight 
the Bolivian government (Olivera 2004). In January 2000, millions of people poured the streets of Bolivia to protest high water charges. The government used violence to disperse protestors. This escalated and broke out into a water war on the streets of Cochabamba (Fuente 2003; Olivera 2004). Finally in April 2000, the Bolivian government terminated the privatization contract and handed over the water and sanitation services to the public agency SEMAPA (Public Citizen 2003). The Bolivian case has become highly symbolic of water privatization opposition.

Privatization contract termination did not improve water services delivery in Cochabamba. SEMAPA, the local municipal authority in charge of water and sanitation services has been drawn into massive debts. It assumed a debt of $\$ 20$ million dollars left off by the private company and the government has not done much to pay it (Fuente 2003). Currently, about 40 percent of the city of Cochabamba's population remain without dependable water access (Assies 2003).

\section{Case Study: Nelspruit, South Africa}

Compared to all the case study countries, South Africa has the best water access statistics with about $91 \%$ of households enjoying access. Agriculture uses $63 \%$ of the annual water use, the lowest compared to all the case study countries. Universal water access is protected in the nation's constitution (McDonald and Ruiters 2005).

South African water privatization has been characterized by both successes and challenges (McDonald and Ruiters 2005) . Following the end of apartheid rule, South 
Africa embarked on major public sector reforms. Water reforms aimed at improving access. The Department of Water Affairs is the responsible umbrella agency for water management. The government has divolved water management to local authorities while the big municipal centers have been opened up to foreign multinational companies (McDonald and Ruiters 2005). Local authorities have the liberty to privatize their water services independent of the government (Foshee et al. 2008).

In 1999, the Nelspruit Local Authority signed a 30 year concession contract with Biwater, a British multinational water company, despite local opposition. The concession has been described as the largest and most complicated municipal water privatization scheme in South Africa (McDonald and Ruiters 2005). The local government argued for privatization on three grounds: to ensure increased capital investment; improve operational efficiency of the water sector; and deal with non-payments in the municipal water system (McDonald and Ruiters 2005). The widespread municipal water privatization triggered the formation of The Coalition against Water Privatization in South Africa (CAWP), a nongovernmental organization that organized citizens to oppose the growth of water privatization in South Africa (McDonald and Ruiters 2005).

The years following the contract saw the multinational company Biwater struggling to keep up with the financial burden of investment. After the privatization, water access has greatly improved in the municipality (Public Citizen 2003). Other studies revealed overall improvement in service delivery to towns in larger municipalities (McDonald and Ruiters 2005). In spite of some successes, it has also been plagued with many problems. Water charges have nearly tripled and service supply cut from poor 
communities (Public Citizen 2003). Due to high levels of non payment levels, Biwater has not been able to expand its operational areas (McDonald and Ruiters 2005). Typical with several water privatization cases, the Nelspruit water concession is a work with both successes and failures.

\section{Case Study Conclusions}

The global water crisis is multifaceted and remains both an issue of access and scarcity. The access problem is a factor of allocation while scarcity is mostly a factor of drought, pollution, and climate change. Increasing water demand for households, agriculture, and industry continues to exacerbate the gap between water demand and supply. These case studies share interesting differences and similarities.

The Manila privatization is unique as the largest water concession contract in history. Allegations of public water utility corruption and inefficiency were the chief reasons behind the concession. The concession contract is still ongoing but fraught with many challenges. Bolivia stands out as a clear case of water privatization concession and public opposition. Unaffordable water rates following privatization resulted in intense public violence. South Africa gave local authorities autonomy to manage their own water services including the option of privatization. The privatization case of Nelspruit municipality remains the biggest in Sub-Saharan Africa and has become an important reference in the water privatization discourse in the African continent. The private sector expanded water coverage, however, water charges have increased as a result. 
The experiences from the case studies lay credence to the complex nature of water privatization. It is simplistic to argue for or against privatization as a means to improve water access while overlooking the cases in their respective contexts. Increases in water charges and its impacts of the poor stood out among all the cases. Furthermore, poor, rural communities have been left out of the private sector operations as urban areas become the focus. These developments provoke important questions. Is it possible for the private sector to pursue profit while also working in the interest of poor and marginalized people? How compatible is human right to water with cost recovery operations often pursued by the private sector? Is affordability a measure of human right when it comes to water? Who is responsible for the much needed investment needed to salvage aging water infrastructure especially in developing? In all the three case studies, water privatization produced some results. However, causes of the failures recorded along with the aforementioned questions are important considerations for effective water policies. Furthermore, NGOs played important roles in organizing citizens and other interested groups to oppose water privatization in all the three cases. 


\section{Chapter 4: Literature Review}

Most water privatization studies have focused on evaluating the effectiveness of water privatization in increasing water access (Barrera-Osorio et al. 2009; Elliott 1996; Mustafa and Reeder 2009; Spronk and Webber 2007; Trawick 2003; Wu and Malaluan 2008). There is much debate about water privatization's effectiveness in achieving this goal. Most researchers have therefore focused on evaluating successes and failures of specific aspects of privatization in different areas and regions of the world. Since water privatization is complex, no single researcher has comprehensively studied a particular water privatization case. All the studies have instead focused on a few specific aspects such as operational efficiency, corruption, or the impacts of water privatization on different communities and populations (Casarin et al. 2007; Loftus and McDonald 2001; Miralles 2008; Tornheim et al. 2009).

For instance, Bauer (1997) found that Chilean water privatization markets were more complex than they seemed. While he did not determine whether they had succeeded or failed, his research created a basis for other water privatization studies. These researchers found a mixture of successes and failures. For example, Araral (2009) and Barlow and Clark (2002) argued that water and sanitation privatization has been a total failure. On the other hand, Keenan et al (1999) contended that it is the most effective means of increasing water accessibility. Prasad (2006) said water privatization has resulted in some successes rather than the total failure claimed by critics. 


\section{Water Privatization Research Populations}

Many researchers have assessed water privatization impacts on different groups of people (Mustafa and Reeder 2009; Rodriguez 2004; Tornheim et al. 2009; Vinnari and Hukka 2007; Wu and Malaluan 2008; Zaki and Amin 2009). Their work suggests that the poor and middle classes have been the most negatively impacted because of increased water charges (Bakker 2007; Dumke 2005).

Mustafa and Reeder (2009) investigated the effect of water privatization on water charges and disconnection rates in Belize City. They concluded that privatizing water led to increases in water charges, increased disconnection rates, and a lack of investment by the private sector, all of which negatively impacted poor and middle class community members. Their findings were similar to those of researchers in Peru (Trawick 2003), Argentina (Casarin et al. 2007; Loftus and McDonald 2001), Indonesia (Bakker 2007), Estonia (Vinnari and Hukka 2007), and Mexico (Wilder and Lankao 2006) who found that water privatization led to increased water charges.

\section{Benefits of Water Privatization}

However, some researchers have found benefits. Water privatization in England and Wales led to higher private sector investment in water treatment and provision infrastructure (Saal and Parker 2001). It also led to higher capital investment in France (Lobina and Hall 2007) and financial management improvements in parts of Sub-Saharan Africa (Bayliss 2003). 
Some researchers have gone beyond water pricing impacts to determine whether it increased consumer water access. They found increased welfare benefits sufficient to offset price increases (Mckenzie and Mookherjee 2003). Others found improved drinking water quality and increased water access owing to water privatization in Thailand (Zaki and Amin 2009).

Barrera-Osorio et al. (2009) investigated the impact of water privatization on water access in Colombia. He found out that it increased water access in urban areas. Clark et al. (2009) in Latin America had similar results finding that water privatization led to increased urban water access because more houses were connected to water sources after privatization. Barrera-Osorio et al. (2009) also found that water access decreased in the rural areas of Colombia owing to privatization. Clark et al. (2009) found out that overall, Latin American water privatization increased household water source connections. Similarly, researchers in Argentina found out that water privatization increased water supply although water charges increased as a result (Casarin et al. 2007).

\section{Water Privatization and Public Health}

Many scientists and policy makers criticize water privatization as being ineffective at improving public health through reductions in waterborne diseases. Mulreany et al. (2006) found no compelling scientific evidence that privatization improved Latin American public health. Others determined that Bolivian water privatization led to increased pediatric diarrhea in some communities (Tornheim et al. 2009). Some researchers found out that although British water privatization increased 
infrastructure investment, it did not improve public (Evans and Lowry 1999). On the other hand, Galiani et al. (2005) discovered that water privatization improved drinking water quality and reduced childhood mortality. Similarly, Barrera-Osorio et al. (2009) found that water privatization led to public health improvements in both urban and rural Colombia.

\section{Water Privatization and Corruption}

Private sector and governmental corruption are serious problems in many countries. Where they are prevalent, they can interfere with the effectiveness of water privatization project success. For instance, Nissan et al. (2004) found a great deal of water sector after French privatization. However, others have found that French water privatization actually reduced corruption (Lobina and Hall 2007).

$\mathrm{Wu}$ and Malaluan (2008) concluded that governance is an important influence on water agency performance. Kirkpatrick et al. (2006) tried to understand why water privatization had not been effective in developing economies as opposed to developed economies. They found that inadequate infrastructure investment, and poor governance and regulatory structures are the major causes of water privatization failure in developing economies. Others learned that although water privatization can increase capital investment in water management infrastructure, poor governance and corruption often undermine it (Bakker et al. 2008; Martimort and Straub 2009). Others have argued that private sector operations are often undermined by the inability of the poor to pay for the water services (Dumke 2005). 


\section{Public Resistance to Water Privatization}

Resistance to water privatization growth has increased across the globe (Hall et al. 2005). In their quest to understand why, some researchers concluded that the public oppose privatization contracts in order to prevent shifts from more moderate forms like management contracts, toward more intensive forms like concessions (Barlow and Clark 2002). Hall and Lobina (2006) also found that the risk of a potential transition from weaker to stronger privatization forms has caused community resistance.

Spronk (2007) found Bolivian protests against water privatization on the grounds that it benefited only the middle and upper classes and not the poor. Others determined that public sector restructuring and associated increases in unemployment are a major cause of opposition (Shanker and Rodman 1996). Places where water privatization has encountered opposition include South Africa, Uruguay, Bolivia, Hungary, Germany, Brazil, and Argentina (Hall et al. 2005). Bolivia is often cited as an example of significant opposition when privatization fails to improve public water services (Barlow and Clark 2002; Opel and Shiva 2008). 


\section{NGOs and Global Development}

Nongovernmental or nonprofit organizations are domestic and international organizations that carry out development activities not for profit, and independent of government. These organizations play numerous roles through the global public policy process and development. The ambiguity of what NGO really stands for is well acknowledged in policy and scientific circles (Vakil 1997). The number of development NGOs has increased substantially in recent decades while their activities have also become more resource intensive (Bradshaw and Schafer 2000; Srinivas 2009). NGOs exist and operate at different levels. International nongovernmental organizations usually have a central administrative office with satellite offices and projects located in different parts of the globe. They are defined as organizations that maintain headquarters in economically developed countries but undertake active projects in developing countries (Bradshaw and Schafer 2000). A typical example of an international NGO is CARE International. Several projects in many developing countries are coordinated from its administrative headquarters in the United States. Local or national NGOs however operate on a much smaller scale such as within a country or a community.

Nongovernmental organizations can also be classified by the specific objectives for which they exist. In this case, they fall under categories such as relief agencies, community based organizations (CBOs) and aid agencies. The importance of NGOs in development cannot be overemphasized. Owing to this, many researchers have sought to shed light on their developmental activities. In Pakistan, NGOs have contributed to the provision of basic education (Yousuf et al. 2010). The role of NGOs in education 
delivery has translated into growing global awareness on health and environment (Witteborn 2010). Grassroot coalitions by NGOs in partnership with local communities help to create awareness on important environmental and social issues (Warleigh 2000; Potts-Datema et al. 2005).

NGOs are instrumental in the provision of health services in developing economies (Young and Merschrod 2010; Utzinger et al. 2004; Shircliff and Shandra 2011; Matthias and Green 1994; Gilson et al. 1994). The growth of NGOs has contributed to greater awareness of the HIV/AIDS pandemic (Shircliff and Shandra 2011; Owczarzak 2010; Lawrence and Brun 2011).

NGOs are very active in global environmentalism and advocacy for biodiversity conservation (Pinto 2010). They are major players in rural development and poverty reduction initiatives (Mintzberg and Srinivas 2010; Nugroho 2010). NGOs play a vital role in human right advocacy and justice (Heinz 2010). In times of natural disaster and civil unrest, NGOs provide relief support for victims while also helping to rebuild those communities (Fuest 2010).

In spite of the important role development NGOs play, they also face many challenges. Their struggle with inadequate financial and human resource is well documented (Barr et al. 2005; Ferguson and Heidemann 2009; Gilson et al. 1994; Kang 2011; Miraftab 1997). This makes it difficult for NGOs to achieve their goals in particularly poor communities (Hanchett et al. 2003). Pervasive governance is another challenge (Gilson et al. 1994; Hardoy and Satterthwaite 1991; Nega and Milofsky 2011). They can also face community opposition to their projects (Miraftab 1997; Stilles 2002). 


\section{NGOs and Water, Sanitation, and Health (WASH) Provision}

Provision of clean and safe drinking water is vital to development. It therefore comes as no surprise that improving access to clean water is an important component of the Millennium Development Goals (MDGs). International and national/local NGOs play important roles in water and sanitation provision through a variety of ways (Fuest 2010; Hanchett et al. 2003; Kornatowski 2010; Matthias and Green 1994; Nair and Vohra 2011; Nugroho 2010; Yousuf et al. 2010). For instance, the construction of water wells and bore holes in developing countries have become one of the most important objectives of NGOs to contribute to the achievement of the MDGs on water and sanitation (Bradshaw and Schafer 2000; Hoque and Hoque 1994; Mwendera 2006; Mohan 2003). NGOs work to provide water in areas like urban slums which are often overlooked by private water operators (Cross and Morel 2005). In Bangladesh, NGOs have been involved in combating arsenic poisoning through local community education (Paul 2004). In parts of Tanzania, NGOs are key actors in integrated water resources management (Ngana et al. 2004). In developing countries, NGOs are at the forefront of hygiene and sanitation education in schools and local communities (Mukhtar, Indabawa, and Imam 2010). Some NGOs educate local indigenous communities and help to prevent waterborne diseases (Metwally et al. 2007).

Large international water NGOs such as WaterAid International have been very instrumental in various parts of developing countries putting up water projects in partnership with local NGOs (Hanchett, Akhter, and Khan 2003). In South Africa, an NGO called MVULA TRUST is seen as the largest single most important private player 
in the water sector with over nine regional offices and several water projects (McDonald and Ruiters 2005).

\section{NGOs and Water Privatization}

The role of NGOs in water privatization usually focuses on organizing coalitions against the World Bank and other multinational agencies involved in it. These coalitions have occurred both at the global and local levels. In May 21, 2007, more than 138 civil groups and NGOs from several countries converged in the Netherlands and proposed that The World Bank stops water privatization (TNI 2007). Currently, a group of NGOs in Indonesia have organized concerned citizens to call for the termination of a12 year old water privatization contract in Jakarta, the capital city (The Jakarta Post 2011). In Bolivia, La Coordinadora, an activist NGO, mobilized other groups and citizens to fight against water privatization (Olivera 2004). In South Africa, widespread municipal water privatization triggered the formation of The Coalition against Water Privatization in South Africa (CAWP). The NGO advocated for basic human right to water and called for

more transparency and justice in water pricing. Similarly, activist NGOs Ghana National Coalition against the Privatization of Water (GhanaCAP), and Integrated Social Development Center (ISODEC) were very active in Ghana's water privatization opposition (McDonald and Ruiters 2005).

Although NGOs are important actors in the WASH sector, no empirical study has sought to understand how their staff view water privatization, and how it influences their decision making. Given that these NGOs play an indispensable role in development 
work, and are involved in on the ground work, it is important to understand their views of water privatization. Most water privatization researchers have rather focused on its impacts on consumers (Barrera-Osorio et al. 2009; Clarke et al. 2009; Galiani et al. 2005; Mustafa and Reeder 2009; Spronk, 2007; Trawick 2003). Most of their surveys and interviews have focused on industry employees (Lobina and Hall 2007; Nissan et al. 2004), government officials (Kirkpatrick et al. 2006; Wu and Malaluan 2008), or members of the public (Barrera-Osorio et al. 2009; Clarke et al. 2009; Galiani et al. 2005; Spronk 2007). To fill the gap and contribute to our understanding of how NGO staff perceive water privatization, I have conducted research on development NGO staff views of water privatization and how it affects their water project decision making. 


\section{Chapter 5: Research Design}

The main goal of my research is to contribute to our understanding of water privatization across the globe. Privatization of water and sanitation services has been largely proposed by the World Bank, International Monetary Fund (IMF), and other groups to address global water access problems. Recognizing the important role nongovernmental organizations (NGOs) play in the water, health, and sanitation (WASH) sector, this study focuses entirely on them. To contribute to our knowledge and understanding of water privatization, my objectives for this study are threefold. First and foremost is to compare and contrast perceptions of water privatization between international and national WASH sector NGOs. Secondly, I seek to understand the challenges WASH sector NGOs face while implementing their water, sanitation, and health projects and activities across developing countries. The final objective is to determine how different water management systems (public, private, and public private partnerships) influence WASH sector NGO decision making and to learn the implications.

I used semi structured telephone interviews to collect my data (Longhurst, 2009). I used telephone interviews as opposed to surveys to enable interviewees express themselves and share information in a conversational atmosphere. This helped to elicit important information relevant to the study. Before conducting the interviews, I compiled a database of WASH and development based NGOs including their locations, major activities, addresses, and phone numbers. I selected NGOs for the database using search engines like Google, news articles, and online databases of NGOs. For instance, 
Duke University has an online database of development NGOs categorized into major activities such as poverty, water, sanitation and development among others. National NGOs were selected by calling country consulate offices to ask for contacts of NGOs that have WASH programs. I chose national NGOs in countries where some level of water privatization has occurred. This was particularly important since I sought to understand how experiences of water privatization within countries where NGO carried out their activities may have influenced their overall perceptions of water privatization.

Following the database set up, I then categorized the NGOs into three types. The first was international NGOs with US offices and WASH activities in multiple developing countries. The second category was national NGOs whose WASH activities were restricted to one country. The third category was large multinational NGOs affiliated with the United States government or the United Nations and whose activities involve WASH projects.

This categorization of NGOs was key to understand if NGOs at different levels have different perceptions about the role water privatization plays in development and water access. The United Nations acts as the overarching water policy advocate. However, small NGOs play very important roles as the implementing agencies of UN and US policy goals. They are also in contact with local people and can have a better understanding of problems and challenges on the ground.

I conducted 28 interviews between the periods of January to June 2011. Fifteen were the staff from international NGOs described earlier with offices in the United States while implementing their WASH activities across different parts of developing countries. 
Twelve were staff from national NGOs whose activities are restricted to a country or different areas of developing countries, and finally, 1 interview with an official from the United Nations Children's Emergency Fund (UNICEF).

Prior to the interviews, telephone calls were first placed to the selected organizations to introduce the study and also to request a name of an appropriate official to be interviewed based on the interview questions and the kind of information sought from the organization. I asked for a higher ranking official involved in the decision making and implementation of WASH activities and projects. In instances where there were no phone numbers, I used emails to first contact the organizations and then requested for phone numbers. Subsequent to the first call, a second call was made to speak with the official suggested by the organization, and a date and time set for the interview.

A copy of the interview questions was sent to the interviewees ahead of the scheduled date and time. This was done to reaffirm the confidentiality of the study and non sensitivity of the questions and information being sought. The decision to make questions available followed the initial calls made in which organizations requested for a copy of the questions before they would make someone available for the interview. Secondly, this was done to enable interviewees an opportunity to familiarize themselves with the interview questions ahead of the scheduled date and time. I conducted five pilot interviews to pretest the questions, and based on the responses, edited the questionnaire into a final document which was used for all the subsequent interviews. A typical interview lasted averagely between 30-60 minutes depending on factors such as 
interviewee's interest in the topic and the availability of their time given that most of them had a very busy schedule.

I recorded the interviews using the website www.recordmycalls.com and the audio files downloaded to a computer. One interviewee declined recording her interview but agreed to speak slowly for notes to be taken. Four interviewees however citing busy schedules and inability to give 30 or more minutes of their time completed the questionnaire and sent it as email attachments. The recorded interviews were fully transcribed into text and coded. In order to ensure that files were not mixed with each other, they were labeled with a file name that has interviewers initial as well as date the interview was conducted. A sample file name reads EA Int 101152011 . This implies first interview done by the interviewer with initials EA and conducted on the $15^{\text {th }}$ day of January 2011. Following transcription, interviews were labeled and sorted into questions. Labeling and sorting enables the categorization of transcripts into questions for analysis. Responses to every question were analyzed to determine common themes and interesting trends for the purposes of research discussion. For example, to analyze the question "Does your organization prefer to do water projects in a publicly owned, privately owned, or a public private partnership system", I first coded the responses into four themes A: I will prefer a public system, B: I consider every system equally, C: I will prefer a private system, and D: I will prefer a public private partnership system.

The NGO officials who responded to the interviews ranged from founders and cofounders, program and project officers, to public relations and research directors. Before the start of every interview, a confidentiality statement is read to the interviewees to seek 
their consent to the interviews and recording. Interviewees were also given the liberty to either participate in the study or withdraw at any time if they wanted to.

Questions were asked in the order in which they occurred on the questionnaire. In addition, follow up probing questions were asked where appropriate in the course of the interview. This was to allow interviewees to shed more light on responses that were shallow in depth and required further explanation. Interview questions were divided into three sections. The introduction section focused on questions to elicit basic information on the activities of the organization as well as an overview of their WASH related projects. The second section focused on WASH project implementation and the challenges on the ground while implementing them. The final section was on water privatization and aimed at stimulating discussion on perceptions on water privatization. A full set of interview questions have been included in Appendix A. 


\section{Chapter 6: Results}

This section summarizes the key findings from the above analysis. In all cases, patterns are presented with the number of interviewees whose responses fit the pattern, followed by the percentage of the interviewees represented by this number. Please note that there is a minor deviation in the numbers of people responding to some questions due to question revision or interviewees who chose not to answer a particular question. My percentages were calculated based on the number of people who responded to each question. In some cases, the percentages calculated for the responses add up to more than $100 \%$ because an interviewee may give more than one answer to a question. My presentation of these patterns is often followed by a representative quote illustrative of the manner in which interviewees discussed the material that fit each pattern.

\section{Water Management and Projects}

To understand NGO water project activities, I asked interviewees about their experiences about water projects in various communities. I asked interviewees to explain how local communities often respond to their WASH activities. Fifteen (54\%) of the NGO staff said local communities have responded well to their projects and often provided support in the form of the labor needed for a successful the project successful. On the other hand, seven (25\%) said that local communities generally have not been very supportive to their WASH activities. Seven (25\%) cited cultural and language barriers as the major challenge they face from local communities. Five (18\%) of the interviewees 
expressed that their major concern with local communities is their inability to take appropriate ownership of projects once they complete and leave the area. For example, an interviewee said:

I would say for the most part the communities have responded really well to our water systems and it's basically made safe drinking water accessible to even the poorest

of those communities. Usually the poor people in the community cannot afford to buy bottled water. So our work has really helped improve the quality of life in terms of health and people are appreciative of the work we do. (Interview 14)

\section{Water Project Evaluation and Assessment}

I also asked interviewees about their understanding of what constitutes a successful water project. I asked them about how they usually evaluate and assess the success or failure of their WASH projects. Water access numbers and public participation are the most important criteria mentioned by interviewees. Fifteen (54\%) of the interviewees said they focus on water access numbers following their projects to determine successes or failures. Fifteen (54\%) said the number of people who participated in the project is an important criterion for evaluation. Ten (36\%) said they public health as a criterion to evaluate projects. Eleven (39\%) mentioned water quality, three (10\%) mentioned gender equity and women involvement, and four (14\%) mentioned financial efficiency of projects as an important indicator of success. A summary of the results are presented in Table 6.1. 
Table 6.1

Criteria for WASH project assessment and evaluation $(\mathrm{N}=28)$.

\begin{tabular}{|l|c|c|}
\hline \multicolumn{1}{|c|}{ Criterion } & Responses (n) & Response (\%) \\
\hline Number of beneficiaries & 15 & 54 \\
\hline Public participation & 15 & 54 \\
\hline Public health & 10 & 36 \\
\hline Water quality & 11 & 39 \\
\hline Gender equity/ involvement of women & 3 & 10 \\
\hline Cost effectiveness & 4 & 14 \\
\hline Adequate training of community members & 5 & 18 \\
\hline Behavioral changes & 9 & 32 \\
\hline
\end{tabular}

Note: Total percentages exceed $100 \%$ because some interviewees gave multiple answers.

\section{Opinions on Water Privatization}

My primary objective was to determine how opinions on water privatization differed among NGO staff. I therefore asked their opinions of water privatization. Eight $(29 \%)$ of the interviewees said that privatization of water is good and plays an important role in increasing water access. Their most common reason was the need for increased private water sector investment in the face of inadequate public sector financial capital. For instance, one interviewee said:

I don't think water privatization is bad. The big water companies play an important role in water provision. The mission of the anti-corporate and ant $i$ - 
privatization people is not to get water to people. They are just anti corporate organizations. (Interview 8)

Most of the interviewees who expressed positive beliefs about water privatization also discussed the need to do it properly especially in developing countries. For example, referring to developing countries, one interviewee explained:

Actually, I will say privatization is a very broad term. There has always been some level of private involvement with water services. However, I will say that private control of water is too risky especially in the long term. It can be helpful in the short term but very dangerous to pursue in the long term. (Interview 2)

Thirteen $(46 \%)$ of the interviewees stated that water privatization is a bad idea and never increases water access. Their primary rationale were that it is risky and that it leads to increased water charges for poor people who can ill afford the added cost. For example, one of these individuals told:

Well I definitely think that it is a bad thing. Particularly it is bad for the customers because in most situations their water rates increases and transparency disappears. There is no way to really hold private companies accountable. It is also bad for the utility workers as well. People who have municipal jobs before don't get hired when private companies come in. I think it is such a bad deal. (Interview 7) 
Seven $(25 \%)$ of the interviewees had mixed beliefs whether water privatization is good or bad. Some of these interviewees explained that whether water is publicly or privately controlled is not as important as making sure that people get access to clean and affordable water. Also, some of them believed that different factors could make privatization either fail or succeed. Some of them thought that both public and private water management have advantages and disadvantages. In the quote below, an interviewee expressed mixed beliefs about water privatization:

Well my philosophy personally about water privatization is that I really don't care how people get water. If they get water that is good quality, and it is a sustainable system that is locally owned, then I am for it. It does not matter how you score your points in a game, but it matters how many you score and win the game. Let me give you a good example. In Cochabamba, and I am sure you have read about that, before the problem with privatization down there, the Cochabamba people did not have safe water. During the privatization, the people still did not have safe water. After the privatization problem, the people still did not have safe water. That is a problem. (Interview 3)

Seven $(25 \%)$ interviewees supported micro level water privatization where private companies emerge within communities to manage their water services. They believed that local, rather than multinational companies, should be given contracts to manage municipal water services. Three (10\%) believed that public private partnerships were the best forms of water privatization and should be encouraged. Two (7\%) said that water privatization is good for urban areas with large populations but not rural areas where they are mostly poor people who cannot afford the high costs of privately provided water. 
Also, some of them cited aging water management infrastructure as the reason why public private partnerships were important as one said:

My opinion on water privatization is that it very much varies from place to place and also in terms of scale. If you talk about local water provision of water such as people selling water in jerry cans by the side of the road, that is a pos itive initiative. This involves more than a single benefit for the community by creating employment, raising standards of living, and al so providing water. Having said that, I can also think of a macro level privatization by multinational water companies which has led to the decline in standards of supply and s ervice, and al so lack of investment in infrastructure. (Interview 11)

A summary of their perceptions of water privatization is presented in Table 6.2.

Table 6.2

Interviewee perceptions of water privatization $(\mathrm{N}=28)$.

\begin{tabular}{|l|c|c|}
\hline \multicolumn{1}{|c|}{ Opinion } & Response (n) & Response (\%) \\
\hline Water privatization is bad. & 13 & 46 \\
\hline Water privatization is good. & 8 & 29 \\
\hline Water privatization is neither good nor bad. & 7 & 25 \\
\hline Water privatization is only good for urban areas. & 2 & 7 \\
\hline Community based water privatization is good. & 7 & 25 \\
\hline
\end{tabular}

Note: Total percentages exceed $100 \%$ because some interviewees gave multiple answers. 


\section{Sources of Perceptions of Water Privatization}

Interviewees were also asked how their ideas on water privatization were formed. The intent for this question was to understand if the opinions were grounded in experiential knowledge or based on media hearsays. Fourteen $(50 \%)$ of the interviewees work for NGOs that have carried out some water projects in areas where different forms of water privatization have occurred. The results show that their experiences working in such areas directly impacted their perceptions on water privatization. In the following quote, an interviewee explains what has shaped his ideas about water privatization:

I know about it because it is happening in Malawi. A lot of companies here have been sold to private people. Major corporations have been sold to individuals or companies and currently, they want to hand over other utilities to companies so that they manage the utilities for people to have quality services. On the quality services I have no problem, but only worry is that water will be expensive for ordinary people like my grandparents in the village. (Interview 17)

Thirteen (46\%) of the interviewees said that they have not had any water projects in areas where water privatization has occurred. Opinions from this category of interviewees were based on di fferent reasons. Twelve (43\%) learned about water privatization from media sources. Three (11\%) said that their ideas on water privatization came from interactions with colleagues in other NGOs. One interviewee with no experience working in an area with water privatization said: 
I had read about it a lot when I worked with the UN and also read about it in Indonesia because I were there to see how my work will succeed in that system. (Interview 6)

I also analyzed responses from the staff whose water privatization perceptions were influenced by the media. The idea was to determine the extent to which positive and negative opinions of water privatization were influenced by the media. Out of the 12 responses with media influence, four (33\%) said water privatization is good and can increase water access while five (41\%) said water privatization is bad. Three (25\%) of the interviewees in this category had mixed opinions about water privatization and could not say whether it is good or bad. From these results, I cannot conclude whether the media has greater influence on interviewees positive or negative perceptions of water privatization.

Interviewees were also asked to cite examples of water privatization successes or failures that they know of. The idea was to understand how much interviewees knew about specific global water privatization cases. Fourteen (50\%) of the interviewees were unable to mention specific successful or failed global water privatization cases. An example can be seen in the following quote:

I am as bad as anybody that I can't name successes for you. It's not something that I really follow. It's a little bit embarrassing that I cannot name some successes but it just something that I do not follow a lot. (Interview 16) 
Twelve (43\%) of the interviewees were able to name examples of either a successful or failed water privatization case. For instance, an interviewee said:

I will say Manila in Philippines was a success and of course Cochabamba Bolivia was a failure. (Interview 2)

Table 6.3 summarizes the sources of water privatization beliefs shared by interviewees.

Table 6.3

Sources of beliefs of water privatization $(\mathrm{N}=28)$.

\begin{tabular}{|l|c|c|}
\hline \multicolumn{1}{|c|}{ Opinion } & $\begin{array}{c}\text { Response } \\
\text { (n) }\end{array}$ & $\begin{array}{c}\text { Response } \\
\text { (\%) }\end{array}$ \\
\hline I worked in an area where water privatization occurred. & 14 & 50 \\
\hline $\begin{array}{l}\text { I have not worked in an area where water privatization } \\
\text { occurred. }\end{array}$ & 13 & 46 \\
\hline $\begin{array}{l}\text { I have learnt about water privatization from the media. } \\
\begin{array}{l}\text { I have learnt about water privatization from colleagues } \\
\text { in NGOs. }\end{array}\end{array}$ & 3 & 11 \\
\hline
\end{tabular}

Note: Total percentages exceed $100 \%$ because some interviewees gave multiple answers.

\section{Water Privatization and NGO Decision Making}

A goal of this study was to understand how NGO staff perceptions of water privatization influence their organizational water project decision making. The interviewees were therefore asked their preferences for public, private, or public private 
partnership water management. I then asked questions about how the presence of one versus the other in a country or community affected their choices regarding developing projects within that area.

Nine $(32 \%)$ of the interviewees said that they preferred purely public water systems. The reasons for their preference ranged from increased risk associated with privatization to privatization's negative impacts on poor communities. These results were not surprising since thirteen $(46 \%)$ had earlier told me that they did not believe water privatization ever had any positive effects. An example of a response from an interviewee when asked what the water management preference of his NGO will be is shown in the quote below:

Public, of course because a lot of people will benefit from it compared to the private. Most of our work is community based so we prefer a public system. The thing is that not everybody can afford to pay so when it is community based, then those who can afford will help those who cannot afford. It is better than private. (Interview 1)

Sixteen $(57 \%)$ responded that they had no preferences for one management system over another. For these interviewees, whether a system is publicly or privately owned did not influence their NGO's decision making. They instead said the factors that affected their judgments about where to locate projects were poverty levels, office locations, level of area need for increased water access, and donor preferences for investment in particular areas. For instance, one said: 
It does not come into our decision making at all. You know NGO is 'nongovernmental organization' so we work with people that are not in the government in the developing world. As much as possible, we usually avoid working with government officials as much as possible. We have to of course adhere to governmental rules and regulations and we do that but we try to always have minimum interaction with the government. (Interview 4)

One (4\%) had no preferences at all between public, private, or a public private partnership. This response came from a staff from an NGO which work in remote rural areas with critical water needs. The interviewee explained:

I think I would have to say no because when we are talking about developing world context, whether the system is public or private, the reach of those utilities is relatively limited there are always high percentage of people who do not have access to that supply. It would not really be a consideration for us. We would be working with communities that are not exposed to those supplies anyway. (Interview 11)

Two (8\%) interviewees said they preferred public private partnerships as one explained below:

In public-private partnership because then you take advantage of the efficiency of the private partners, but have the public partner that will ensure service to all (including low-income areas). A public-private partnership should also include the users in its design, then it becomes demand-driven and is more legitimate. (Interview 24) 
Table 6.4 summarizes these findings.

Table 6.4

Water privatization and interviewee decision making $(\mathrm{N}=28)$.

\begin{tabular}{|l|c|c|}
\hline \multicolumn{1}{|c|}{ Decision } & $\begin{array}{c}\text { Responses } \\
\text { (n) }\end{array}$ & $\begin{array}{c}\text { Response } \\
\text { (\%) }\end{array}$ \\
\hline I do not factor it into my decision. & 16 & 57 \\
\hline I prefer to work with a publicly owned system. & 9 & 32 \\
\hline $\begin{array}{l}\text { I prefer to work with a public private } \\
\text { partnership. }\end{array}$ & 2 & 4 \\
\hline $\begin{array}{l}\text { I will not invest in either private or public } \\
\text { systems. }\end{array}$ & 1 & \\
\hline
\end{tabular}

\section{Water Privatization Perceptions Comparison between International and Local/National NGO Staff}

In order to determine if international and national/local NGO staff have different perceptions of water privatization, I compared 15 international and 12 national/local NGO staff perceptions. The two groups do not appear to differ significantly in their views of water privatization. Seven (47\%) of the international NGO staff and six (46\%) of the national/local NGO staff expressed negative opinions about water privatization. For instance, an interviewee from a local NGO said:

Generally my experience with water privatization has been very bad and I can give you an example. In one area where we were putting water infrastructure, we were 
told that a new system was coming in by the local water board. They said the people coming in were promising huge infrastructure. When the company came in, the community could not afford the project so they were asked to leave the area. They had signed a 30 year contract with the municipality but it was such a corrupt system that they were asked to withdraw. (Interview 26)

Five $(33 \%)$ of the international NGO staff and three (23\%) of national/local NGO staff said water privatization is good and can increase water access. In the quote below, an international NGO interviewee explains why he thinks water privatization is good:

I mean I don't think that privatization has to be bad. The point is that we want to make sure that they are not taking advantage of the poor. On the other hand, I think the big companies can play an important role in water provision. For me the anti-corporate and anti-privatization people in the water sector like the Food and Water Watches, and Maude Barlow are not water organizations. They are just anti corporate organizations. (Interview 8)

Four (20\%) international and three (31\%) of national/local NGO staff had mixed perceptions of water privatization. Table 6.5 summarizes these results. 
Table 6.5

Water privatization perceptions between international and local NGO Staff $(\mathrm{N}=\mathbf{2 8})$

\begin{tabular}{|l|c|c|c|c|}
\hline & \multicolumn{2}{|c|}{ International (N=15) } & \multicolumn{2}{c|}{ National/Local (N=13) } \\
\hline \multicolumn{1}{|c|}{ Opinion } & $\begin{array}{c}\text { Response } \\
\text { (n) }\end{array}$ & $\begin{array}{c}\text { Response } \\
\%\end{array}$ & $\begin{array}{c}\text { Response } \\
\text { (n) }\end{array}$ & $\begin{array}{c}\text { Response } \\
\%\end{array}$ \\
\hline Water privatization is bad. & 7 & 47 & 6 & 46 \\
\hline Water privatization is good. & 5 & 33 & 3 & 23 \\
\hline $\begin{array}{l}\text { Water privatization is neither } \\
\text { good nor bad. }\end{array}$ & 3 & 20 & 4 & 31 \\
\hline
\end{tabular}

\section{Perceptions of Water Privatization Failure}

Interviewees were asked what they think are the causes of water privatization failure. This was to understand from their water project experiences, the major reasons for water privatization failure. Seventeen $(61 \%)$ said the major reason why water privatization fails is high water charges. This was consistent with the number of people who also said water privatization is bad. Seven (25\%) said a lack of transparency and public involvement causes water privatization to fail. Three (11\%) said the World Bank and IMF are the causes of water privatization failure. For example, an interviewee who blamed water privatization failure on high water charges said:

It fails because people cannot afford the water. That is probably the bottom line of water privatization failure. Most developing countries don't have a middle class and certainly in the rural areas, there is no middle class. These people cannot afford high cost of water. (Interview 4) 
An interviewee who was of the opinion that lack of transparency and public involvement are the major causes of water privatization failure said:

I think cost of water is one of the biggest reasons why water privatization is not feasible. Also, because it's a private company, the public has little or no input in the way they operate. They are not usually transparent. The public are not able to hold the private companies accountable. The goal of the private company is always to make profit and not to serve the public. (Interview 7)

Table 6.6 summarizes the results from this section.

Table 6.6

Perceptions of Water Privatization Failure

\begin{tabular}{|l|c|c|}
\hline \multicolumn{1}{|c|}{ Cause of failure } & $\begin{array}{c}\text { Response } \\
\text { (n) }\end{array}$ & $\begin{array}{c}\text { Response } \\
\text { (\%) }\end{array}$ \\
\hline High water charges. & 17 & 61 \\
\hline Lack of transparency and public involvement. & 7 & 25 \\
\hline The IMF and World Bank. & 3 & 11 \\
\hline Lack of understanding of local communities. & 3 & 11 \\
\hline Lack of responsibility on the part of government. & 2 & 7 \\
\hline Local community opposition. & 1 & 3 \\
\hline Not answered. & 3 & 11 \\
\hline
\end{tabular}

Note: Total percentages exceed $100 \%$ because some interviewees gave multiple answers. 


\section{Chapter 7: Discussion}

Numerous studies have documented perceptions of water privatization (BarreraOsorio et al. 2009; Mustafa and Reeder 2009; Wu and Malaluan 2008). My study results are consistent with the mixed perceptions of water privatization evident in this literature. Some researchers argue that water privatization is an ineffective way to increase water access (Araral 2009; Barlow and Clark 2002; Dumke 2005). Many of my interviewees share this view as thirteen $(46 \%)$ told me that water privatization does not increase water access globally.

The rationales cited by interviewees with negative perceptions of water privatization were consistent with those from the studies (Casarin et al. 2007; Loftus and McDonald 2001; Mustafa and Reeder 2009; Trawick 2003). They argued that water privatization leads to unaffordable water charges in many poor and middle class households. These results were also consistent with interviewee perceptions of what causes water privatization failure as seventeen $(61 \%)$ of them said high water charges is the major cause.

However, eight (29\%) of my interviewees believed that water privatization can improve capital investment and financial management. This is consistent with the arguments of other researchers (Bayliss 2003; Lobina and Hall 2007; Saal and Parker 2001).

My findings indicate that although many interviewees had negative water privatization opinions, for the majority, the presence of privatized water systems did not 
tend to affect their water project decision making. This was particularly surprising since at the outset of this study, I expected that NGOs would prefer to do projects in areas with publicly owned water systems.

Two (7\%) interviewees asserted that water privatization is only beneficial in urban areas. These ideas are consistent with studies on water privatization that concluded that water privatization leads to increases in water access in urban areas (Barrera-Osorio et al. 2009; Clarke et al 2009).

My results confirm the divided nature of the global water privatization debate. This may be in part because the successes or failures of privatization is contingent on local conditions and circumstances (Prasad 2006). Outcomes of water privatization are affected by different factors. On one hand, there is frequently a critical need for increased investment in the water sector of developing countries. On another hand, increasing this investment through privatization (or increased public funding) can make water access unaffordable for poor households. Interviewees' arguments in support of water privatization were based on the urgency of water need as well as the need for more capital investment in the areas where they work. However, their arguments against it were grounded in the levels of poverty in the remote areas where they work, and the likelihood that communities will not be able to afford high costs of water. It is important to note that both public and private water management has their advantages and disadvantages.

My findings suggest that interviewees' water privatization perceptions were often based on their experiences working in areas where water privatization has occurred. 
However, their perceptions were also frequently shaped by media portrayals of water privatization. This supports claims by other water governance experts that arguments against water privatization are not based on adequate understanding of the tradeoffs associated with public versus private water management (Bakker 2010). Furthermore, the results of my study also indicate that the media influenced both the negative and positive interviewee perceptions of water privatization.

My findings also suggest that there are no significant differences on water privatization perceptions between international NGO and national/local NGO staff. I found that five (33\%) of the international NGO staff and three (23\%) of national/ local NGO staff expressed positive perceptions about water privatization while seven (47\%) international and six (46\%) national/local NGO had negative opinions about it. Three (20\%) international and four (31\%) national/local NGO staff had mixed perceptions of water privatization. 


\section{Chapter 8: Conclusions and Recommendations}

The global water crisis has many causes. With over one billion people lacking access to clean water and over two billion lacking improved sanitation facilities, the situation is serious. The situation is worsened by climate change, population growth, and pollution which threaten both freshwater quality and quantity. Solutions are lacking. Privatization remains one possible solution. However, my results demonstrate that it is quite controversial among NGO staff who work every day to try to solve problems like lack of water access. Many of my interviewees oppose water privatization. Furthermore, based on my study results, development NGO staff see high water charges and lack of transparency and public involvement as the main reasons why water privatization fails.

Contrary to common negative media portrayals of water privatization, I found out that many development NGO staff either viewed it positively or positively under specific circumstances because it had the potential to provide the badly needed financial investment in developing world water sector infrastructure.

These results raise a difficult question. Who bears the ultimate responsibility to invest in the water sector and ensure sustainable water supply? All over the world, especially in developing countries, water systems are deteriorating at alarming rates. This calls for investment to keep water systems sustainable. The private sector's involvement has increased investment in many places. Unfortunately, this increased investment has also increased water charges beyond what the average person can afford. The complexities and the divisive nature of these ideas were evident in my study. 
From the results, a considerable number of the development NGO staff see the need for private sector involvement. However, their perceptions raise some important questions. Can the private sector work in the interest of both poor and rich people? Can governments contract the private sector while putting in place policies to subsidize the cost of water for poor and middle class citizens? These questions are very important considerations for water sector policies that seek to involve the private sector.

The development NGO staff also see the need for private sector involvement under specific circumstances. First and foremost, the entire water privatization contract process is transparent and engages all important actors. Secondly, governments hold private companies accountable for their water delivery activities. This will ensure that poor and middle class communities also have access to the water provided by private water company. Multinational water companies operate as a monopoly. Usually, one company operates within a particular community or municipality. Without government intervention and oversight responsibility, there is the tendency for them to largely focus on profits and overprice water at the expense of customers.

My study also sought to understand how public and private water management could influence the decision making of development NGOs. At the outset of this study, I recognized the importance of development NGOs in the global public policy process and development. It was therefore important to see if the sentiments and ideas on water privatization had the tendency to translate into water project decision making. I conclude that although many of my interviewees were opposed to water privatization, it does not usually influence their water project decision making. 
From the results of my study, none of the NGO officials were of the opinion that their organizations will have sole preferences in investing in privately owned water systems. Majority of the NGO officials claimed that privatization regardless of its merits and demerits will not influence their water project decision making. However, a few number of officials preferred to work in only publicly owned water systems.

The debate on water privatization continues. The perceptions in both policy and scientific circles are mixed. Based on my study, privatization of water is not entirely bad nor is public water systems devoid of problems. Both systems have their advantages and disadvantages. Public water systems have failed especially in the area of capital investment. Private water management has increased water sector investment. However, the increased investment has also led to high water charges. An important question is how much of the global water crisis problem can privatization solve? Water demand and supply have various dimensions. There are local factors that either cause privatization to fail or succeed aside how private water companies operate. It is important to always put the public private debate in its appropriate context before conclusions are drawn.

My work has contributed to the larger context of the water privatization debate through a documentation of the diversity of NGO staff views on this issue. Given that NGOs work on the ground to provide water as part of their development activities, the views of water privatization expressed in this study are very important for water policies as we seek effective solutions to address the global water crisis. 


\section{Study Limitations}

However, my work has limitations. The interpretations and analysis of this study is based on responses that reflect the ideas of one individual from a diversity of NGOsperhaps if I had interviewed multiple people in each NGO, I would have gotten different results that more fully present shared organization perspectives on the issue.

In addition, I only interviewed 28 people. A broader quantitative survey of staff in more development NGOs could better establish the generalizability of my findings. The analyses of the results were based on only 28 interviews.

\section{Recommendations for Future Study}

While this study focused on NGOs across the globe and the perceptions of their officials on water privatization, it would be interesting to narrow the scope to countries with widespread privatization of water such as Bolivia, the Philippines, or South Africa to understand how private sector involvement impacted on the activities of NGOs on the ground.

Another avenue for future study is the emerging small-scale water privatization. To date water privatization researchers have largely focused on the activities of large multinational companies such as Suez, Vivendi, and Bechtel Corporation. It is important to study the activities of local small-scale private companies to understand the differences and similarities between their activities and those of multinational companies. 
Finally, the results of this study are based on staff from 28 development NGOs. A related study with a larger sample of staff from selected development NGOs will be interesting. The conclusions from such a study can be used to gauge the overall of perceptions of NGOs about water privatization compared to my study which focused on one interviewee from each selected NGO. 


\section{Literature Cited}

Araral E. 2009. The failure of water utilities privatization:Synthesis of evidence, analysis and implications. Policy and Society 27(3):221-228.

Ashton PJ. 2002. Avoiding Conflicts over Africa's Water Resources. Journal of the Human Environment 31(3):236-242.

Assies W. 2003. David versus Goliath in Cochabamba - Water rights, neoliberalism, and the revival of social protest in Bolivia. Latin American Perspectives 30(3):14-36.

Bakker K. 2007. Trickle Down? Private sector participation and the pro-poor water supply debate in Jakarta, Indonesia. Geoforum 38(5):855-868.

Bakker K, Kooy M, Shofiani NE, and Martijn EJ. 2008. Governance Failure: Rethinking the Institutional Dimensions of Urban Water Supply to Poor Households. World Development 36(10):1891-1915.

Bakker K. 2010. Privatizing Water:Governance Failure and The World's Urban Water Crisis. Ithaca and London: Cornell University Press.

Bantay T. 2010. Targeting Privatization: The Philippines. Cited 2011 July 27. Available from http://www.righttowater.info/ways-to-influence/human-rights-approach2/targeting-privatisation-the-philippines/

Barlow M, Clark T. 2002. Blue Gold:The Fight to Stop the Corporate Theft of the World's Water. New York: The New York Press.

Barr A, Fafchamps M, Owens T. 2005. The governance of non-governmental organizations in Uganda. World Development 33(4):657-679. 
Barrera-Osorio F, Olivera M, Ospino C. 2009. Does Society Win or Lose as a Result of Privatization? The Case of Water Sector Privatization in Colombia. Economica 76(304):649-674.

Bauer CJ. 1997. Bringing water markets down to earth: The Political Economy of water rights in Chile, 1976-1995. World Development 25(5):639-656.

Bayliss K. 2003. Utility privatization in Sub-Saharan Africa: A case study of water. Journal of Modern African Studies 41(4):507-531.

BBC 2004. Water Privatization Gains Support. BBC. Cited 2011 July 25.

Available from http://news.bbc.co.uk/2/hi/uk_news/scotland/3566939.stm

BBC 2008. Water Victory for South African Townships. Cited 2011 July 25.Available from http://news.bbc.co.uk/2/hi/africa/7375972.stm

BBC 2008. Water Privatization is Ruled Out. BBC. Cited 2011 July 25. Available from http://news.bbc.co.uk/2/hi/uk_news/northern_ireland/6739873.stm

Bradshaw YW, Schafer MJ. 2000. Urbanization and development: The emergence of international nongovernmental organizations amid declining states. Sociological Perspectives 43 (1):97-116.

Brown D. 2007. Pulling the Plug on Wasting Water. BBC. Cited 2011 July 25. Available from http://news.bbc.co.uk/2/hi/science/nature/6943956.stm

Brubaker E. 2000. Privatizing water works: As Halifax considers a private-sector solution to its sewage problem, Elizabeth Brubaker debunks critics' claims that water privatization is a failure. The National Post. Cited 2011 July 30. Available from http://www.lexisnexis.com/hottopics/lnacademic. 
Budds J, McGranahan G. 2003. Are the debates on water privatization missing the point? Experiences from Africa, Asia and Latin America. Environment and Urbanization 15(2):87-113.

Casarin AA, Delfino JA, Delfino ME. 2007. Failures in water reform: lessons from the Buenos Aires's concession. Utilities Policy 15(4):234-247.

Castro JE. 2008. Neoliberal Water and Sanitation Policies as a Failed Development Strategy: Lessons from Developing Countries. Progress in Development Studies $8(1): 63-68$.

Clarke GRG, Kosec K, Wallsten S. 2009. Has Private Participation in Water and Sewerage Improved Coverage? Empirical Evidence From Latin America. Journal of International Development 21(3):327-361.

Conhead I. 2002. Development and the Upland Resource Base:Economics and Policy, \& Lessons from a Philippine Watershed. Philippine Journal of Development 29(1):1-32.

Cronin J. 2005. Tanzania Ditches Private Water Supplier. BBC. Cited 2011 July 25. Available from http://news.bbc.co.uk/2/hi/business/4558725.stm

Cross P, Morel A. 2005. Pro-poor strategies for urban water supply and sanitation services delivery in Africa. Water Science and Technology 51 (8):51-57.

Dumke NM. 2005. Water privatization threatens low-income families. Journal of the National Medical Association 97(2):141-141.

Dumol M. 2000. The Manila Water Concession: A key Government Official's Diary of the World's Largest Largest Water Privatization. Washington D. C: The World Bank. 
Elliott C. 1996. Privatization and employment relations: The case of the water industry Davidson,JOC. International Journal of Manpower 17(3):52-54.

Evans D, Lowry R. 1999. The privatized water industry and dental public health: water fluoridation? Community Dental Health 16(2):65-66.

Evans T. 2010. 'Water justice' advocate: Don't privatize. CNN. Cited 2011 July 25. Available from http://www.cnn.com/2010/TECH/science/01/07/water.justice.

Ferguson KM, Heidemann G. 2009. Organizational strengths and challenges of Kenyan NGOs serving orphans and vulnerable children: a template analysis. International Journal of Social Welfare 18(4):354-364.

Fisher KT. 2009. Urban water supply and local neoliberalism in Tagbilaran City, the Philippines. Asia Pacific Viewpoint 50(2):185-197.

Flow 2008. DVD. Directed by Irena Salina. Oscilloscope Laboratories Video.

Foshee JR, Ghosh A, Graham C, Murray W, Ruben-Salama C. 2008. Thirsty for Change: Considering Water Privatization in Developing Countries. Cited 2011 July 25. Available from www.thinkpdf.com/39/391406bbd37209f9-download.pdf

Fuente MDL. 2003. The water war in Cochabamba, Bolivia: Privatization triggers an uprising. Mountain Research and Development 23(1):98-100.

Fuest V. 2010. Contested Inclusions: Pitfalls of NGO Peace-Building Activities in Liberia. Afrika Spectrum 45(2):3-33.

Fuest V, Haffner SA. 2007. PPP - policies, practices and problems in Ghana's urban water supply. Water Policy 9(2):169-192. 
Galiani SP, Gertler PJ, Schargrodsky E. 2005. Water for life: The impact of the privatization of water services on child mortality. Journal of Political Economy 113(1):83-120.

Gilson L, Sen PD, Mohammed S, Mujinja P. 1994. The Potential of Health sector Nongovernmental Organizations - Policy Options. Health Policy and Planning $9(1): 14-24$.

Gleick PHG, Wolff EL, Chalecki EL, Reyes R. 2002. The Worlds Water: The Biennial Report on Freshwater Resources. Washington: Island Press.

Goldman M. 2007. How "Water for All!" policy became hegemonic: The power of the World Bank and its transnational policy networks. Geoforum 38(5):786-800.

Graff J. 2007. A Thirst for Growth. Times. Cited 2011 July 27. Available from http://www.time.com/time/magazine/article/0,9171,1599691,00.html

Hall D, Lobina E. 2006. Pipe Dreams: The failure of the private sector to invest in water services in developing countries. London: World Development Movement.

Hall D, Lobina E, de la Motte R. 2005. Public resistance to privatization in water and energy. Development in Practice 15(3):286-301.

Hanchett S, Akhter S, Khan MH. 2003. Water, sanitation and hygiene in Bangladeshi slums: an evaluation of the WaterAid-Bangladesh urban programme. Environment and Urbanization 15(2):43-55.

Hardoy JE, Satterthwaite D. 1991. Environmental-Problems of Third-World Cities - A Global Issue Ignored. Public Administration and Development 11(4):341-361. Heinz WS. 2010. The Effectiveness of Domestic Human Rights NGOs. A Comparative Study. European Journal of International Law 21 (2):493-494. 
Hooker L. 2008. Ghana's Daily Struggle for Water. BBC. Cited 2011 July 25. Available from http://news.bbc.co.uk/2/hi/business/7761588.stm

Hoque BA, Hoque MM. 1994. Partnership in Rural Water Supply and Sanitation - a Case-Study from Bangladesh. Health Policy and Planning 9(3):288-293.

Ismail I. 2003. Keeping tabs on privatization. The New Straight Times. Cited 2011 July 31. Available from http://www.lexisnexis.com/hottopics/lnacademic/?

Jehl D. 2003. As Cities Move to Privatize Water, Atlanta Steps Back. New York Times. Cited 2011 July 26. Available from http://www.nytimes.com/2003/02/10/national/10WATE.html?scp=2\&sq=water\% 20privatization\&st $=$ cse

Johnston E, Murakami A. 2003. Water forum closes amid clash over privatization. The Japan Times. Cited 2011 July 31. Available from http://www.lexisnexis.com/hottopics/lnacademic/?

Kang J. 2011. Understanding non-governmental organizations in community development: Strengths, limitations and suggestions. International Social Work 54(2):223-237.

Keenan SP, Krannich RS, Walker MS. 1999. Public Perceptions of Water Transfers and Markets: Describing Differences in Water Use Communities. Society \& Natural Resources 12(4):279-292.

Kirkpatrick C, Parker D, Zhang YF. 2006. An empirical analysis of state and privatesector provision of water services in Africa. World Bank Economic Review 20(1):143-163. 
Kornatowski G. 2010. Patnerships and governance: Struggle, cooperation, and the role of NGOs in welfare delivery for the homeless in Hong Kong. City, Culture, and Society 1:155-164.

Kurniawan MN. 2003. Water privatization a controversial step around the world. The Jakarta Post. Cited 2011 July 30. Available from http://www.lexisnexis.com/hottopics/lnacademic/?

Lawrence PG, Maria CB. 2011. NGOs and HIV/AIDS Advocacy in India: Identifying the Challenges. South Asia-Journal of South Asian Studies 34(1):65-88.

Lobina E, Hall D. 2007. Experiences with Private Sector Participation in Grenoble,France, and Lessons on strengthening public water operations. Utilities Policy 15(2):93-109.

Loftus AJ, McDonald AD. 2001. Of liquid dreams: a political ecology of water privatization in Buenos Aires. Environment and Urbanization 13(2):179-199.

Marin P. 2009. Public-Private Patnerships for Urban Water Utilities: A Review of Experiences in Developing Countries. The World Bank. Cited 2011 July 22. Available from http://www.ppiaf.org/ppiaf/sites/ppiaf.org/files/FINALPPPsforUrbanWaterUtilities-PhMarin.pdf .

Martimort D, Straub S. 2009. Infrastructure privatization and changes in corruption patterns: The roots of public discontent. Journal of Development Economics 90(1):69-84.

Matthias AR, Green AT. 1994. The comparative advantage of NGO (non-governmental organizations) in the health sector--a look at the evidence. World Hosp Health Serv 30(1):10-15. 
McDonald DA, Greg R. 2005. The Age of Commodity: Water Privatization in Southern Africa. London: Earth Scan.

Mckenzie D, Mookherjee D. 2003. The distributive impact of privatization in Latin America: Evidence from four countries. Economica 3(2):161-233.

Metwally AM, Saad A, Ibrahim NA, Emam HM, El-Etreby LA. 2007. Monitoring progress of the role of integration of environmental health education with water and sanitation services in changing community behaviours. International Journal of Environmental Health Research 17(1):61-74.

Mintzberg H, Srinivas N. 2010. Juxtaposing doers and helpers in development. Community Development Journal 45(1):39-57.

Miraftab F. 1997. Flirting with the enemy: Challenges faced by NGOs in Development and Empowerment. Habitat International 21(4):361-375.

Miralles A. 2008. The link between service privatization and price distribution among consumer types: municipal water services in the Spanish region of Catalonia. Environment and Planning C-Government and Policy 26(1):159-172.

Mohan RVR. 2003. Rural water supply in India: Trends in institutionalizing people's participation. Water International 28 (4):442-453.

Mukhtar MD, Indabawa II, Imam TS. 2010. Public health implications of sewage ponds in Kano metropolis, Nigeria. Journal of Food Agriculture \& Environment 8(2):2531.

Mustafa D, Reeder P. 2009. 'People Is All That Is Left to Privatize': Water Supply Privatization, Globalization and Social Justice in Belize City, Belize. International Journal of Urban and Regional Research 33(3):789-808. 
Mwendera EJ. 2006. Rural water supply and sanitation (RWSS) coverage in Swaziland: Toward achieving millennium development goals. Physics and Chemistry of the Earth 31 (15-16):681-689.

Nair N, Vohra N. 2011. The case of OD in an NGO in India. Journal of Management Development 30(2):148-159.

Nega B, Milofsky C. 2011. Ethiopia's anti-NGO law and its consequences for economic development. Community Development Journal 46(2):33-48.

Ngana JO, Mwalyosi RBB, Yanda P, Madulu NF. 2004. Strategic development plan for integrated water resources management in Lake Manyara sub-basin, NorthEastern Tanzania. Physics and Chemistry of the Earth 29 (15-18):1219-1224.

Nissan E, Hall D, Lobina E, De la Motte R. 2004. A formalism for a case study in the watertime project: The city water system in Grenoble, from privatization to remunicipalization. Applied Artificial Intelligence 18(3):305-366.

Nugroho Y. 2010. NGOS, The Internet and Sustainable Rural Development :The case of Indonesia. Information Communication \& Society 13(1):88-120.

Olivera O. 2004. Cochabamba!Water War in Bolivia. Cambridge: South End Press.

Opel A, Shiva V. 2008. From water crisis to water culture. Cultural Studies 22(3):498509.

Owczarzak J. 2010. Activism, NGOs, and HIV Prevention in Postsocialist Poland: The Role of "Anti-Politics". Human Organization 69 (2):200-211.

Palaniappan M, Gleick PH, Hunt PH, Srinivasan V. 2004. Water Privatization: Principles and Practices. In The Worlds Water: The Biennial Report on Freshwater Resources, edited by P. H. Gleick. Washington D.C: Island Press. 
Paul BK. 2004. Arsenic contamination awareness among the rural residents in Bangladesh. Social Science \& Medicine 59 (8):1741-1755.

Pereira LS, Oweis TB, Abdelaziz Z. 2002. Irrigation Management Under Water Scarcity. Agricultrual Water Management 57(3):175-206.

Perreault T. 2008. Custom and Contradiction: Rural Water Governance and the Politics of Usos y Costumbres in Bolivia's Irrigators' Movement. Annals of the Association of American Geographers 98(4):834-854.

Pimentel D, Houser J, Preiss E, White O, Fary H, Mesnick L, Barsky T, Tariche S, Schreck J, Alpert S. 1997. Water Resources: Agriculture, the Environment, and Society: An Assessment of the Status of Water Resources. Bioscience 47(2):97106.

Pinto RG. 2010. Building the next ark: how NGOs work to protect biodiversity. International Environmental Agreements-Politics Law and Economics 10(3):267271.

Postel S. 1998. Water for Food Production: Will There be Enough in 2025? Bioscience 48(8):629-637.

Potts-Datema W, Becky JS, Howard T, Theresa CL, James FB, Sharon M. 2005. Successful strategies and lessons learned from development of large-scale partnerships of national non-governmental organisations. Promot Educ 12(34):131-7.

Prasad N. 2006. Privatisation results: Private sector participation in water services after 15 years. Development Policy Review 24(6):669-692. 
Public C. 2003. Water Privatization Fiascos: Broken Promises and Social Turmoil. Washington D.C: Public Citizen.

Robinson S. 2004. Against the Tide: Keeping Water out of Private Hands. Times Magazine .Cited 2011 August 8. Available from http://www.time.com/time/specials/packages/article/0,28804,1995235_1995382_ 1995551,00.html.

Rodriguez R. 2004. The debate on privatization of water utilities: A commentary. International Journal of Water Resources Development 20(1):107-112.

Saal DS, Parker D. 2001. Productivity and price performance in the privatized water and sewerage companies of England and Wales. Journal of Regulatory Economics 20(1):61-90.

Shanker A, Rodman L. 1996. Public-private partnerships. Journal American Water Works Association 88(4):102-107.

Shircliff EJ, Shandra JM. 2011. Non-Governmental Organizations, Democracy, and HIV Prevalence: A Cross-National Analysis. Sociological Inquiry 81 (2):143-173.

Solo TM. 1999. Small Scale Entreprenuers in the Urban Water and Sanitation Market. Environment and Urbanization 11(1):117-132.

Spronk S, Webber JR. 2007. Struggles against accumulation by dispossession in Bolivia The political economy of natural resource contention. Latin American Perspectives 34(2):31-47.

Srinivas N. 2009. Against NGOs? A Critical Perspective on Nongovernmental Action. Nonprofit and Voluntary Sector Quarterly 38(4):614-626. 
Stilles K. 2002. International support for NGOs in Bangladesh: Some unintended consequences. Word Development 30(5):835-846.

Taglabue J. 2002. As Multinationals Run the Tap, Anger Rises Over Water for Profit. The New York Times. Cited 2011 July 26. Available from http://www.nytimes.com/2002/08/26/international/americas/26WATE.

Tapped 2009. DVD. Directed by Stephanie Soechtig.

The Hindu 2005. Delhi Residents Rally against Water Privatization. Editorial. Cited 2011 July 30.Available from http://www.lexisnexis.com/hottopics/lnacademic/?

The Jakarta Post 2011. NGO calls for end to Water Privatization. Editorial. Cited 2011 July 25. Available at http://www.thejakartapost.com/news/2011/06/07/ngo-callsend-water-privatization.html.

Thirst 2004. DVD. Directed by Alan Snitow and Deborah Kaufman. Edited by Kenji Yamamoto.

Times Magazine 2005. Water on the War Front. Editorial. Cited 2011 July 26. Available from http:/www.time.com/time/magazine/article/0,9171,1139827,00.html.

TNI 2007. NGOs Ask Donors to Drop World Bank Water Privatization. Cited 2010 July 25. Available from www.tni.org/archives/media_ppiaf .

Tornheim JA, Morland KB, Landrigan PJ, Cifuentes E. 2009. Water Privatization, Water Source, and Pediatric Diarrhea in Bolivia Epidemiologic Analysis of a Social Experiment. International Journal of Occupational and Environmental Health 15(3):241-248. 
Trawick P. 2003. Against the privatization of water: An indigenous model for improving existing laws and successfully governing the commons. World Development 31(6):977-996.

UNICEF 2010. Water Sanitation and Hygiene. Cited 2011 March 6. Available from http://www.unicef.org/wash/index_statistics.html.

USAID, 2007. The Global Water Crisis. Cited 2011 March 7. Available from http://www.usaid.gov/our_work/environment/water/water_crisis.html.

US Army Corps 2004. Water Resources Assessment of Bolivia (WRAB). Cited 2011 July 1. Available at http://www.sam.usace.army.mil/en/wra/Bolivia/FINAL\%20BOLIVIA\%20WRA \%20COMBINED\%2013\%20DEC\%202004.pdf

Utzinger J, Kaspar W, Daugla DM, Marcel T, Burton HS. 2004. Community health outreach program of the Chad-Cameroon petroleum development and pipeline project. Clinics in occupational and environmental medicine 4 (1):9-26.

Vakil AC. 1997. Confronting the classification problem: Toward a taxonomy of NGOs. World Development 25 (12):2057-2070.

Vinnari EM, Hukka JJ. 2007. Great expectations, tiny benefits - Decision-making in the privatization of Tallinn water. Utilities Policy 15(2):78-85.

Warleigh A. 2000. The hustle: citizenship practice, NGOs and 'policy coalitions' in the European Union - the cases of Auto Oil, drinking water and unit pricing. Journal of European Public Policy 7(2):229-243.

WHO 2010. Progress on Sanitation and Drinking Water. Cited 2011 July 27. Available http://whqlibdoc.who.int/publications/2010/9789241563956_eng_full_text.pdf 
WHO 2011. Water Sanitation and Health (WSH). Cited 2011 July 25. Available from http://www.who.int/water_sanitation_health/hygiene/en/.

Wilder M, Lankao PR. 2006. Paradoxes of decentralization: Water reform and social implications in Mexico. World Development 34(11):1977-1995.

Witteborn S. 2010. The role of transnational NGOs in promoting global citizenship and globalizing communication practices. Language and Intercultural Communication $10(4): 358-372$.

Wu X, Malaluan NA. 2008. A tale of two concessionaires: A natural experiment of water privatisation in Metro Manila. Urban Studies 45(1):207-229.

Young FW, Merschrod K. 2010. Child Health and NGOs in Peruvian Provinces. Social Indicators Research 98 (2):291-299.

Yousuf MI, Alam MT, Sarwar M, Naseer-ud-Din M. 2010. Non-governmental organizations' service quality for development of basic education in Pakistan. African Journal of Business Management 4(14):3201-3206.

Zaki S, Amin A. 2009. Does Basic Services Privatisation Benefit the Urban Poor? Some Evidence from Water Supply Privatisation in Thailand. Urban Studies 46(11):2301-2327. 


\section{Appendix A: Interview Questions Protocol}

\section{Human Subjects Research Approval Number: M0691}

\section{[Confidentiality Statement]}

Thank you for allowing me to interview you. This should take 20-40minutes. I am interviewing non-governmental organizations that are into water provision in different countries especially in developing countries to understand their views of water privatization. This is part of my master's thesis research towards my degree in Environmental Policy at Michigan Technological University. Although none of my questions are sensitive or very personal, your answers remain very confidential. They will only be used for my research purposes and your name will not be associated with anything you say. To help me have a copy of the interview to enable me replay and analyze it, it will help if I am able to tape record it. Are you comfortable with this?

\section{Interview Questions}

\section{General}

1. What is your position in this NGO / what kind of work do you do in this NGO?

2. How long have you worked in this field? Have you been affiliated to other NGOs in the past? 
3. What are the main development issues that this NGO is concerned with? [Can you briefly tell me about the history of your involvement in water projects?]

4. What factors does your NGO consider in deciding which countries/regions/areas to undertake water projects/What you consider before investing in water projects?

5. How much influence/control do your donors have on your decision making? [Do your donors determine your choice of areas for projects? How much autonomy does your organization have?]

\section{Water Management and Projects}

6. What are some of the challenges you have faced in the implementation of water projects?

7. If you were to assess a water project and judge it as a success or failure, what would be your criteria? What are the indicators you will use for the assessment/ Evaluation of your water projects? 
8. How do local communities respond to your water projects on the ground? Can you share your experiences on that with me?

\section{Water Privatization}

9. In your opinion, what is/ What constitutes water privatization

10. What is your general opinion of water privatization? Has it been helpful or bad? Why?

11. Have you been involved in water projects in an area where water privatization has occurred? If yes, did it impact your views of water privatization? If not, what has shaped your views on water privatization?

12. Do you think public private partnership in the ownership of water can help improve water access? If not, what do you think can be done improve water access in developing countries 
13. Would your NGO prefer to do water projects in a publicly owned, privately owned, or a public private partnership water system? Why?

14. Do you think privatization can help improve water access in developing countries? Why? Why not?

15. Based on your experiences in water projects, what do you think are some of the reasons why water privatization may fail to improve water access? Or help improve water access?

16. Can you describe a particularly successful water privatization project? And a particularly unsuccessful water privatization project? 